\title{
Ethnomedicinal plants used for the treatment of dermatological affections on the Purépecha Plateau, Michoacán, Mexico
}

\section{Flora etnomedicinal utilizada para el tratamiento de afecciones dermatológicas en la Meseta Purépecha, Michoacán, México}

\author{
Roberto Esquivel-García' (D), Emmanuel Pérez-Calix² (D), Alejandra Ochoa-Zarzosa³ (D) \\ Martha-Estrella García-Pérez ${ }^{1,4}$ (i)
}

1 Universidad Michoacana de San $\mathrm{Ni}$ colás de Hidalgo, Facultad de Químico Farmacobiología, Morelia, Michoacán, Mexico.

2 Instituto de Ecología, A.C., Red de Diversidad Biológica del Occidente Mexicano, Pátzcuaro, Michoacán, Mexico.

3 Universidad Michoacana de San Nicolás de Hidalgo, Centro Multidisciplinario de Estudios en Biotecnología-Facultad de Medicina Veterinaria y Zootecnia, Tarímbaro, Michoacán, Mexico.

4 Author for correspondence: margarc@live.ca

Received: January 8, 2018.

Reviewed: February 13, 2018.

Accepted: April 24, 2018

Online first: August 8, 2018

Published: October 3, 2018

To cite as:

Esquivel-García, R., E. Pérez-Calix, A. Ochoa-Zarzosa and M.-E. García-Pérez. 2018. Ethnomedicinal plants used for the treatment of dermatological affections on the Purépecha Plateau, Michoacán, Mexico. Acta Botanica Mexicana 125: 95-132. DOI: 10.21829/ abml25.2018.1339

$\mathrm{DOI}$

10.21829/abml25.2018.1339

\section{ABSTRACT:}

Background and Aims: Inhabitants of the Purépecha Plateau preserve an excellent ancestral knowledge on medicinal plants used for dermatological affections, which has not been documented. An ethnopharmacological survey was carried out in this region to gather information on the use of medicinal plants and herbal preparations for treating dermatological affections, to disseminate the Purépecha indigenous knowledge and identifying promising plants for developing new formulations for cutaneous conditions. Methods: The study was conducted in the 21 municipalities that compose the Purépecha Plateau. A total of 86 local inhabitants (62 women and 24 men) were interviewed. The data were quantitatively analyzed through the determination of the use value, fidelity level and informant consensus factor.

Key results: A total of 97 plant species belonging to 47 families were documented for treating 19 dermatological conditions on the Purépecha Plateau. Asteraceae was the leading family among the collected medicinal plants $(20.61 \%)$, followed by Lamiaceae $(13.40 \%)$ and Solanaceae $(5.15 \%)$. The largest number of plants was used for the treatment of cuts $(40.20 \%)$, skin inflammation $(37.11 \%)$ and rash $(37.11 \%)$. The aerial parts were the most commonly used $(34.75 \%)$. The medicinal plant species with larger use values were Heterotheca inuloides (0.53), Aloe vera $(0.37)$ and Oenothera rosea $(0.21)$. The comparison of results with ethnomedicinal literature worldwide revealed that $8.25 \%$ of plants used on the Purépecha Plateau were recorded for the first time for the treatment of dermatological affections.

Conclusions: This study provides new information on medicinal plants used on the Purépecha Plateau to treat cutaneous diseases. Future pharmacological and toxicological investigations are required to demonstrate the efficacy and safety of these species for treating dermatological affections.

Key words: dermatological diseases, ethnomedicine, herbal preparations, Purépecha, skin.

\section{Resumen:}

Antecedentes y Objetivos: Los habitantes de la Meseta Purépecha conservan un excelente conocimiento ancestral sobre plantas medicinales utilizadas para tratar afecciones dermatológicas que no ha sido documentado. Un estudio etnofarmacológico fue realizado en esta región para recopilar información sobre el uso de plantas medicinales y preparaciones herbarias utilizadas en la zona para el tratamiento de afecciones dermatológicas, con el objetivo de difundir la medicina tradicional Purépecha e identificar plantas prometedoras en el desarrollo de tratamientos para afecciones cutáneas.

Métodos: El estudio se realizó en los 21 municipios que componen la Meseta Purépecha. Se entrevistó a un total de 86 habitantes locales ( 62 mujeres y 24 hombres). Los datos se analizaron cuantitativamente mediante la determinación del valor de uso, nivel de fidelidad y el factor de consenso informante.

Resultados clave: En total 97 especies de plantas pertenecientes a 47 familias fueron documentadas para el tratamiento de 19 afecciones dermatológicas en la Meseta Purépecha. Asteraceae fue la familia principal entre las plantas colectadas (20.61\%), seguida de Lamiaceae (13.40\%) y Solanaceae (5.15\%). La mayor cantidad de plantas se utilizó para tratamiento de heridas $(40.20 \%)$, inflamación de la piel (37.11\%) y erupciones cutáneas (37.11\%). La principal parte utilizada de la planta fue la aérea (34.75\%). Las plantas medicinales con mayores valores de uso fueron Heterotheca inuloides (0.53), Aloe vera (0.37) y Oenothera rosea (0.21). La comparación de los resultados con la literatura etnomedicinal reveló que $8.25 \%$ de las plantas utilizadas en la Meseta Purépecha se registraron por primera vez para tratamiento de afecciones dermatológicas.

Conclusiones: Este estudio proporciona nueva información sobre plantas medicinales utilizadas en la Meseta Purépecha para tratamiento de enfermedades cutáneas. Se requieren futuras investigaciones farmacológicas y toxicológicas para demostrar la eficacia y seguridad de estas especies para el tratamiento de afecciones dermatológicas.

Palabras clave: enfermedades dermatológicas, etnomedicina, preparaciones herbarias, Purépecha, piel. 


\section{INTRODUCTION}

Skin diseases have been considered as the fourth leading cause of nonfatal disease burden worldwide (Hay et al., 2014). These conditions are widespread, being one of the most prevalent and disabling diseases and a source of considerable loss of life quality of patients. In rural populations, they are supposed to be one of the most common ailments (Policepatel and Manikrao, 2013). Skin affections have been related to clinical depression, anxiety and suicidal ideation, which represent a major additional problem with a significant negative impact for health systems (Dalgard et al., 2015).

Although in Mexico there are no extensive studies about the prevalence of skin diseases, the main reasons for dermatological consultation in the country are related with acne vulgaris, followed by psoriasis and melasma (HGM-SSA, 2012). In rural zones, the most frequent skin diseases are parasitic, viral and fungal infections as well as dermatitis and eczema (Paek et al., 2012).

Low adherence to treatments has been described for skin ailments (Storm et al., 2008; Augustin et al., 2011). Consequently, people frequently use natural products, mainly in undeveloped areas in which traditional herbal medicines play an important role in the management of these conditions (Sharma et al., 2014). In addition, many dermatological diseases have no cure (psoriasis, melanoma, pemphigus, etc.), so it is important to identify promising plants used in traditional medical systems to develop new therapeutic candidates. The ethnomedical studies remain very important in the discovery of new drugs and in the development of improved herbal preparations for use by local people (Heinrich and Gibbons, 2001).

The state of Michoacán, bordered by the states of Colima, Jalisco, Guanajuato, Querétaro, México and Guerrero is one of the regions of Mexico with the greatest diversity of plant species, many of which used for medicinal purposes (Medina, 2003). In pre-Hispanic times, this region was the home of the Purépecha Empire, which was centered on the Pátzcuaro lake basin. At that time, the Purépechas used copper agricultural tools in an exceptional way, compared to other Mesoamerican cultu- res (Amézcua Luna and Sánchez Díaz, 2015). They had a social stratification represented by the king, followed by knights, priests, and communities of farmers, fishermen, artisans and merchants (Amézcua Luna and Sánchez Díaz, 2015). Nowadays, the Purépecha people live mostly in the highlands of Central Michoacán, with a very important number of them on the Purépecha Plateau. The Purépechas preserve their language, traditions and customs, including an excellent ancestral knowledge of medicinal plants to treat various human health problems (INEGI, 2004).

The Purépecha Plateau is a rich reservoir of biodiversity which includes woody and herbaceous plants, the most important belonging to the genera Quercus L., Salvia L., Gnaphalium L., Senecio L., Eupatorium L., Bidens L., Tagetes L., Stevia Cav., Pinus L., Cirsium Mill., Adiantum L. and Dalea L. (Bello-González et al., 2015). Today, the participation of traditional Purépecha therapists in health services in this region is very important, mainly in those places where the public health system is still deficient (BDMTM, 2009).

Despite the importance of folk medicine by Purépechas, no ethnopharmacological studies are available about the use of plants for the treatment of dermatological conditions by this population. Therefore, it is considered that the documentation of Purépecha ethnomedicinal knowledge is required to identify promising plants for developing new therapeutic candidates or improved herbal preparations in the future.

Keeping the previously mentioned facts in mind, the present study was undertaken to scientifically enumerate medicinal plants and herbal preparations used by inhabitants of the Purépecha Plateau for the treatment of dermatological affections. Additionally, the ethnomedicinal studies performed on these plants are discussed to know whether other communities worldwide use the plants here reported for treating skin conditions, to estimate the contribution of this investigation to the global ethnopharmacological knowledge. Additionally, this study allows for the identification of plants to treat skin pathologies, which opens new perspectives for performing future phytoche- 
mical, toxicological and pharmacological investigations with extracts or pure compounds from natural origin.

\section{Materials and Methods}

\section{Study area}

The state of Michoacán, formally "Michoacán de Ocampo", is situated in the western part of Mexico between $20^{\circ} 23^{\prime} 27^{\prime \prime}$ and $17^{\circ} 53^{\prime} 50^{\prime \prime} \mathrm{N}$ latitude; $100^{\circ} 03^{\prime} 32^{\prime \prime}$ and $103^{\circ} 44^{\prime} 49^{\prime \prime} \mathrm{W}$ longitude, with a surface of $59,864 \mathrm{~km}^{2}$, which represents $3.04 \%$ of the Mexican territory (Mercado-Vargas and Palmerín Cerna, 2012). The state is very rich in biological diversity with around 5000 plant species described, several of them with medicinal properties (Medina, 2003). Additionally, it possesses a unique cultural heritage regarding the use of different natural preparations for many illnesses.

The present study was conducted on the Purépecha Plateau, which is located in the central-northwestern part of Michoacán, belonging to the Trans-Mexican Volcanic Belt. The area includes mountains and volcanoes such as Paricutín, Tancítaro, San Marcos and Comburindos. Its height ranges from 1700 to $3200 \mathrm{~m}$. The annual mean temperature varies from $12-18^{\circ} \mathrm{C}$, with rainfall concentrated in the summer (Orduña Trejo et al., 1999). The dominant vegetation of this zone is mainly composed by Pinus and species of Quercus and Abies Mill. In the northern part and in the northeastern area of the Purépecha Plateau, tropical deciduous forests are formed by species belonging to Bursera Jacq. ex L., Acacia Mill., Opuntia Mill., Tagetes, Melampodium L. and Euphorbia L., among others (Orduña Trejo et al., 1999).

Twenty-one municipalities compose the Purépecha Plateau (surface area, $7348.64 \mathrm{~km}^{2}$ ): (1) Charapan, (2) Cherán, (3) Chilchota, (4) Erongarícuaro, (5) Los Reyes, (6) Nahuatzen, (7) Nuevo Parangaricutiro, (8) Paracho, (9) Pátzcuaro, (10) Peribán, (11) Quiroga, (12) Tancítaro, (13) Tangamandapio, (14) Tangancícuaro, (15) Tingambato, (16) Tingüindín, (17) Tocumbo, (18) Tzintzuntzan, (19) Uruapan, (20) Zacapu, and (21) Ziracuaretiro. All of them were visited to record the ethnomedicinal information for this study (Fig. 1). The most important reasons that were considered to choose this zone were: a) the important presence of the Purépecha population on the Plateau (78.86\% of its inhabitants) (CDI, 2010) with an inherited knowledge of medicinal plants, $b$ ) the high variety of plant species in this region, c) the significant impact of folk medicine on the health services, and d) the fact that no ethnopharmacological studies related to the treatment of dermatological conditions had been performed in the zone.

\section{Studied population characteristics}

Thirty trips were undertaken all over the Purépecha Plateau from May 2015 to October 2016, to collect information on ethnomedical plants. This period included both dry and rainy seasons. The people from this region were very accessible. Among municipalities, there is variation in the way of dressing, although some elements prevail. It has been noted that the traditional clothing for a woman consists in the use of an apron, often embroidered, as well as an embroidered back strap, woven belt, pleated skirt, embroidered blouse, and a mantle ("rebozo"). Indeed, the "rebozo" is more than a clothing to protect Purépecha women from the cold, its diversity (colorful, embroidered or frayed) is a symbol of their culture (Amézcua Luna and Sánchez Díaz, 2015). The man's outfit consists of a hand-woven sash, a blanket suit, and a hat for daily use. The most important economic activities of this region are the agriculture, forestry and the craft industry (BDMTM, 2009). On the Plateau, $75 \%$ of habitants are bilingual, speaking both Spanish and Purépecha, and 25\% speak Purépecha only (Amézcua Luna and Sánchez Díaz, 2015). This language has been classified as isolated, as no similitudes have been found with other Mesoamerican languages (Cambell, 1997).

Although there are public health services within the Plateau, most Purépechas trust traditional medicine as having positive effects on health. Currently, there are two organizations of Purépecha physicians: indigenous doctors from the 11 towns (Acachuén, Carapan, Chilchota, Etúcuaro, Huáncito, Ichán, Santo Tomás, Tacuro, Tanaquillo, Urén y Zopoco). The first institution, based in Cherán, is the "Clínica del Instituto Nacional Indigenista" 


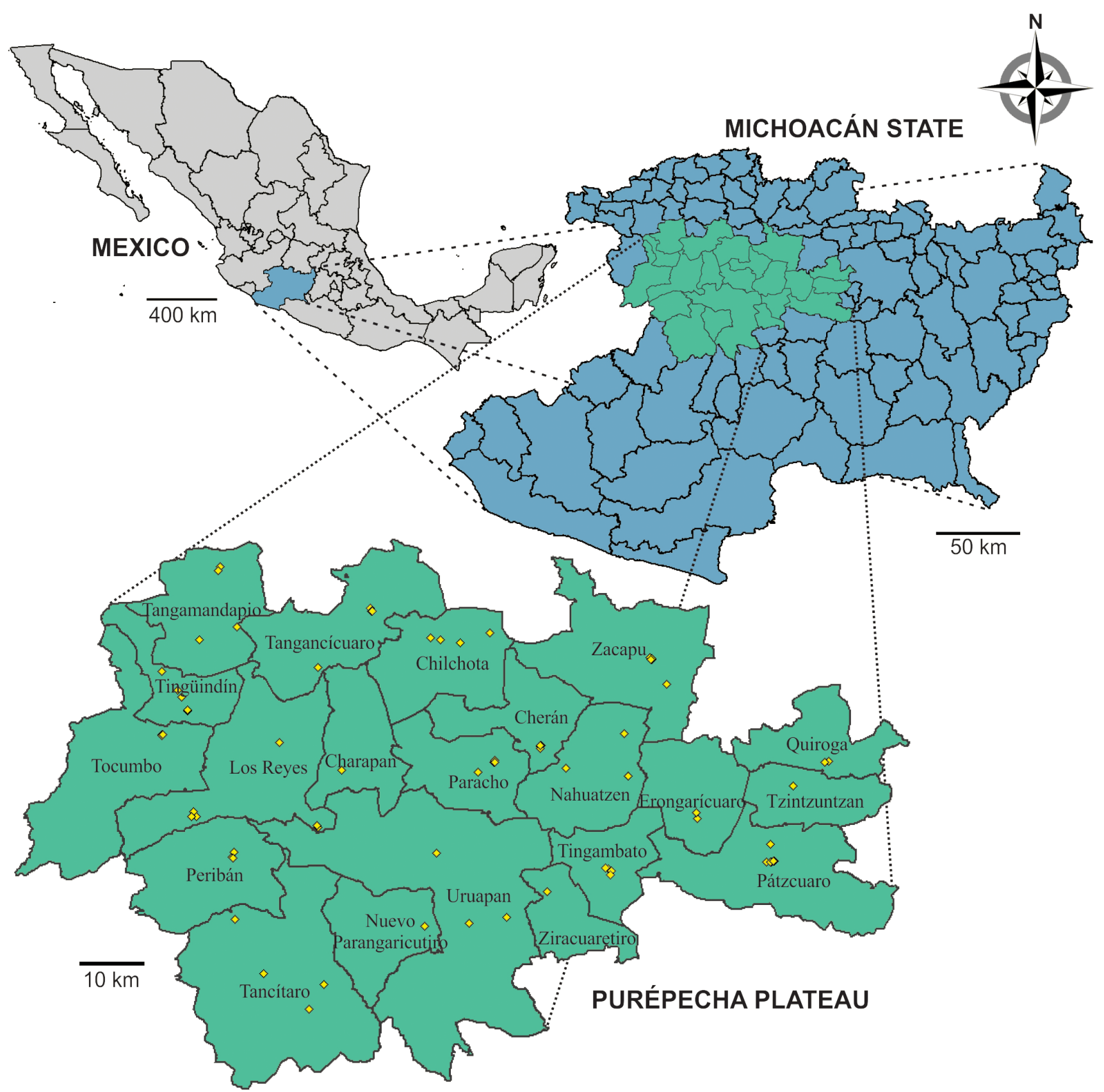

Figure 1: Study area. The diamond-shaped symbols indicate the location where ethnopharmacological surveys were conducted.

(Gallardo Ruiz, 2002); while the second association, currently located in Pátzcuaro, is the "Unidad de Medicina Tradicional". In descending order of importance for Purépechas, these traditional doctors are: healers, midwives, masseurs, sorcerers, bonesetters, herbalists and persons exclusively dedicated to the treatment of baby's fallen fontanelle (BDMTM, 2009).

\section{Ethnomedical survey and plant collection}

The identification of "key informants" was performed as suggested by Bhat et al. (2014), considering the information obtained after discussion with local village people, who recommended these individuals, based on their knowledge regarding the use of plants for treating dermatological affections. Participants were clearly informed about the objec- 
tive of the study and the survey was achieved only when they verbally consented to participate. All of them were also informed about their right to withdraw from the study at any time. Participants were asked about the tissue, method of preparation and mode of administration of plants used for the treatment of skin conditions using a semi-structured questionnaire. Information about age, sex and occupation of informants was compiled and analyzed as shown in Figure

2. Considering that all participants were bilingual and nobody requested to be interviewed in the Purépecha language, the interviews were conducted in Spanish.

The plant specimens collected during the survey were taxonomically identified, and properly labeled with the following data: habitat and size of the organism, flower and fruit color, date of collection, locality, municipality, collection site, altitude, geographical coordinates, plant uses, collector and collection number.
Taxonomic identification was realized based on specialized literature on the sampled taxa and floras of central and western Mexico. In support of identification, the specimens were compared to samples of the herbarium IEB of the Instituto de Ecología, A.C., in Pátzcuaro, Michoacán. Samples identified in the study were deposited in this herbarium with their respective voucher number (Appendix).

\section{Statistical analysis and literature review}

The use value (UV) was calculated for each of the recorded plant species, as proposed by Ferreira et al. (2009). This method allows quantitative evaluation of the relative importance of a determined medicinal plant, considering its use among informants (Ferreira et al., 2009). Higher UV values mean that participants attribute a great significance to a plant, with the advantage that it does not de-
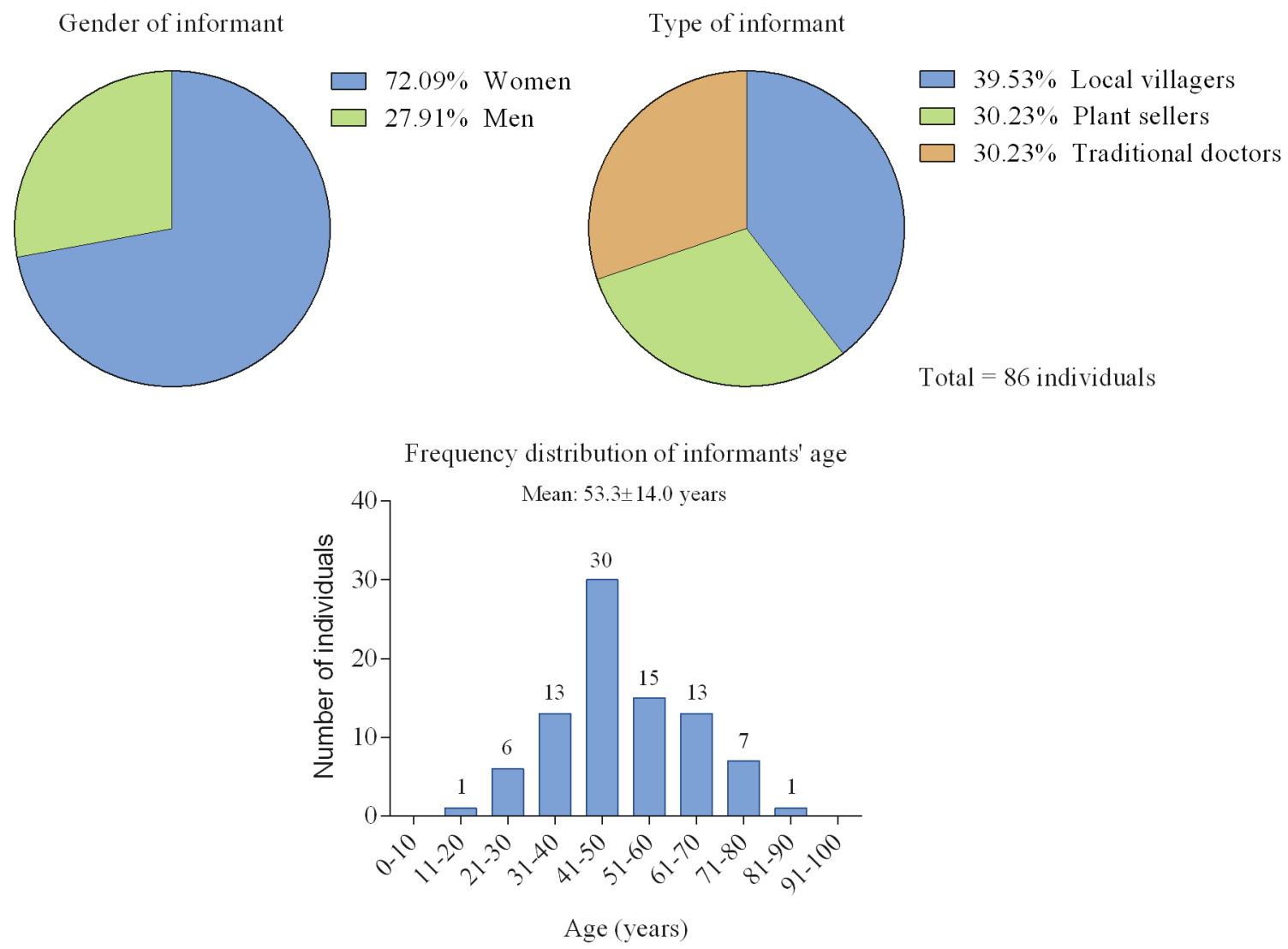

Figure 2: Characteristics of the participants in the ethnopharmacological study on the Purépecha Plateau. 
pend on the researcher opinion. The following equation shows the formula for the evaluation of this parameter, where $U$ is the number of times a species is cited and $n$ the informant number.

$$
\mathrm{UV}=\sum \frac{\mathrm{U}}{\mathrm{V}}
$$

To know how representative a plant was for the treatment of a particular dermatological condition, the fidelity level (FL) was calculated as shown in the next equation (Sharma et al., 2014):

$$
\mathrm{FL}(\%)=\frac{\mathrm{Ip}}{\mathrm{Iu}} \times 100
$$

where Ip is the number of informants who independently indicated the use of a plant for the same particular dermatological condition and Iu the number of informants who mentioned the species for any dermatological condition (Sharma et al., 2014). A plant with high FL (close to 100) is used by traditional healers and people in the community for treating a particular disease. In contrast, a plant with low FL (close to 0.0) indicates that the plant is used to treat diverse diseases (Neamsuvan and Bunmee, 2016).

To estimate the level of agreement between all participants along the Purépecha Plateau about the plant used for each category, the informant consensus factor $\left(\mathrm{F}_{\mathrm{ic}}\right)$ was determined as proposed by Ferreira et al. (2009). Higher values of this factor, close to 1 , were related to a greater consensus between participants (Ferreira et al., 2009). Low values of $\mathrm{F}_{\mathrm{ic}}$ indicate that the participants disagree on the species to be used for treating a particular dermatological affection. The $\mathrm{F}_{\text {ic }}$ was calculated as follows:

$$
\mathrm{F}_{\mathrm{ic}}=\frac{\left(\mathrm{n}_{\mathrm{ur}}-\mathrm{n}_{\mathrm{t}}\right)}{\left(\mathrm{n}_{\mathrm{ur}}-1\right)}
$$

where $\mathrm{n}_{\mathrm{ur}}$ is the number of reports concerning a dermatological category and $n_{t}$ the number of species used for a dermatological affection by all the informants.

When all information was compiled, a detailed review was performed to know whether plants reported in this study were native of Mexico or not (Villaseñor, 2016). Moreover, their use in other ethnomedicinal studies worldwide for the treatment of dermatological disorders was also recorded. Literature was searched from various scientific databases such as Google Scholar, Science direct, Scopus and PubMed. Besides these bibliographic sources, the Digital Library of Traditional Mexican Medicine was also consulted to know the contribution of this work to the ethnopharmacological knowledge in Mexico (BDMTM, 2009).

\section{Results}

The ethnomedicinal information on plants used to treat dermatological affections was collected from 86 individuals of the Purépecha Plateau; detailed information on these persons is shown in Figure 2. They mentioned 731 plant uses and the specimens of collecting plants corresponded to 97 species belonging to 87 genera and $47 \mathrm{fa}-$ milies, which were documented for the first time for the treatment of dermatological conditions in this area. Families frequently used by Purépecha Plateau inhabitants were Asteraceae (20 taxa), Lamiaceae (13) and Solanaceae (5) (Fig. 3), with the genera Salvia (4 spp.), Tagetes (4), Allium L. (2), Artemisia L. (2), Euphorbia (2), and Solanum L. (2) the most represented.

The dermatological conditions were classified into 19 categories according to the symptoms referred by participants as suggested by Sharma et al. (2014). These included blemishes, burns, calluses, cuts, fungal infections, hair fall, hematomas, infections with abscesses, skin inflammation, insect bites, pruritus, psoriasis, rash, skin bumps, skin care, superficial infections, varicella, varicose veins and warts. In this study, $F_{\text {ic }}$ values were found to range between $0.14-0.75$ (Table 1). The highest values were linked with hematomas $(0.75)$, skin inflammation (0.73), varicose veins (0.73) and cuts (0.70), whereas lowest values were found for psoriasis $(0.16)$ and blemishes (0.14). The highest numbers of plants were used for treating cuts (39 spp.), skin inflammation (36) and rash (36), whereas the treatment of warts (3) and calluses (2) was less reported among participants (Fig. 4). 


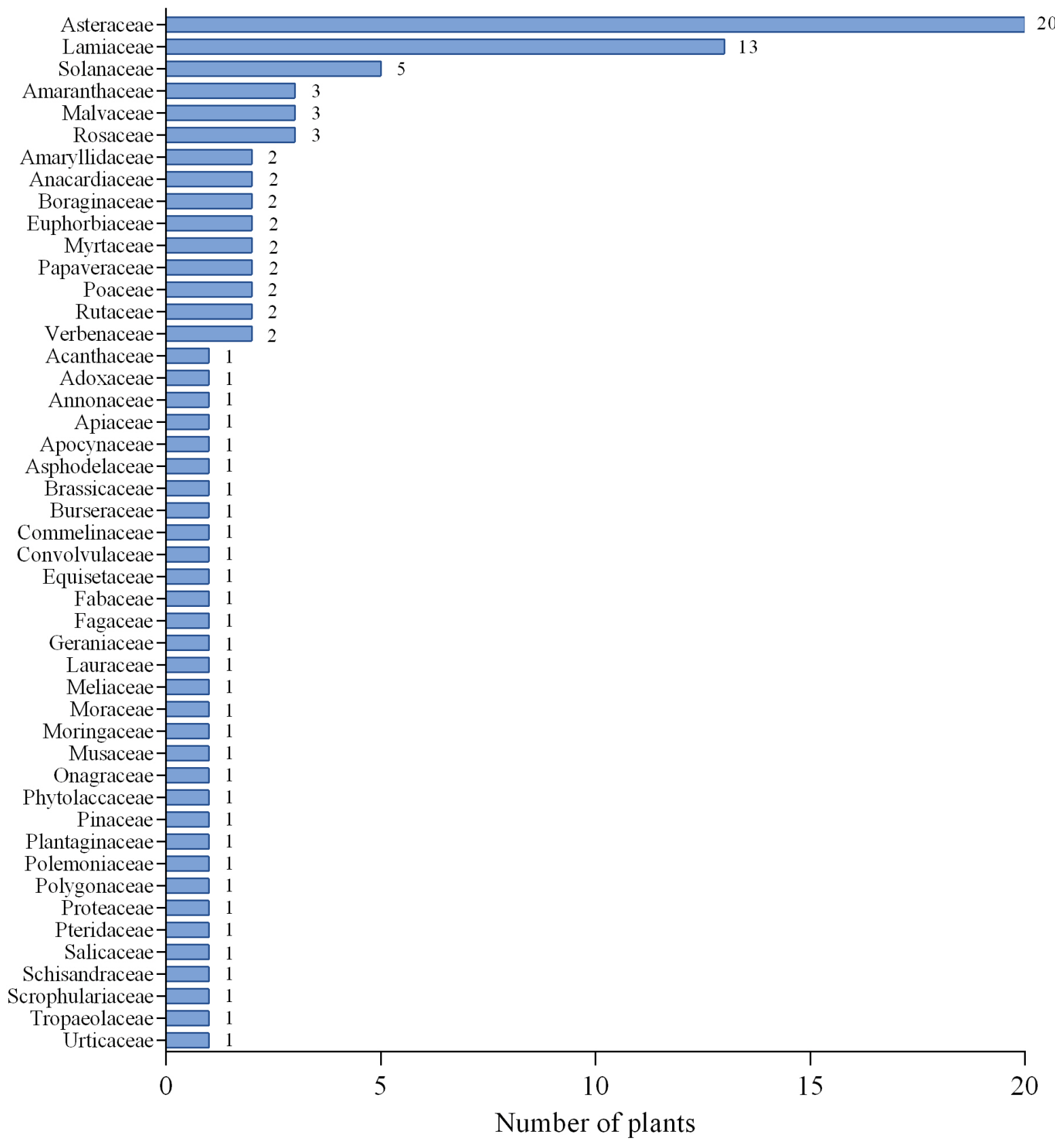

Figure 3: Family distribution of medicinal plants used on the Purépecha Plateau.

As revealed in Figure 5, the aerial parts which consist of a heterogeneous mixture of flowers, leaves and stems were preferred by participants $(34.75 \%)$, followed by leaves $(27.3 \%)$ and flowers $(13.24 \%)$. In relation to the preparation modes, the most important were infusions (52.36\%) and decoctions (15.13\%). The present study also reports the use of common salt (sodium chloride) in small proportions for the preparation of pastes, particularly with the species Senecio salignus DC. and Sida kaenkeana C. Presl. Both plants are employed for treating cuts, hematomas, skin inflammation and skin bumps (Appendix).

Native and introduced plants (56.7 and 43.3\%, respectively) are a valuable resource for local population for treating dermatological ailments (Appendix). According to 
Table 1: Consensus factor values for different dermatological affection categories on the Purépecha Plateau.

\begin{tabular}{ll}
\hline Dermatological affection categories & $\mathrm{F}_{\text {ic }}$ \\
\hline Hematomas & 0.75 \\
Skin inflammation & 0.73 \\
Varicose veins & 0.73 \\
Cuts & 0.70 \\
Calluses & 0.67 \\
Warts & 0.67 \\
Hair fall & 0.66 \\
Rash & 0.61 \\
Burns & 0.60 \\
Skin bumps & 0.59 \\
Skin care & 0.57 \\
Fungal infections & 0.50 \\
Superficial infections & 0.48 \\
Insect bites & 0.48 \\
Pruritus & 0.46 \\
Infections with abscesses & 0.40 \\
Varicella & 0.40 \\
Psoriasis & 0.16 \\
Blemishes & 0.14 \\
\hline
\end{tabular}

the UV, the five most preferred plant species to treat dermatological disorders on the Purépecha Plateau were Heterotheca inuloides Cass. (0.53), Aloe vera (L.) Burm. f. (0.37), Oenothera rosea L'Hér. ex Aiton (0.21), Calendula officinalis L. (0.17) and Urtica subincisa Benth. (0.17) (Fig. 6). Appendix shows the fidelity levels (FL) for each plant recorded in the study. The FL indicates which species are mostly preferred for the study population to treat a given disease. In the present study, 39 species were determined to have the highest fidelity level $(\mathrm{FL}=100 \%)$ for different skin ailments (Appendix). For cuts these plants were Azadirachta indica A. Juss., Commelina diffusa Burm. f., Chenopodium ambrosioides L., Eriobotrya japonica (Thunb.) Lindl., Geranium seemannii Peyr., Leonotis nepetifolia (L.) R. Br., Piqueria trinervia Cav., Sonchus oleraceus L., Tagetes lucida Cav. and Tagetes remotiflora Kunze, for fungal infections Zea mays L., for hair fall Buddleja sessiliflora Kunth and Verbena carolina L., for infections with abscesses Ipomoea murucoides Roem. \& Schult. and Lepidium virginicum L., for insect bites Iresine interrupta Benth. and Tanacetum parthenium (L.) Sch. Bip., for rash Ceiba aesculifolia (Kunth) Britten \& Baker f., Euphorbia nutans Lag., Lactuca sativa L. Montanoa tomentosa Cerv., Origanum majorana L., Physalis pubescens L., Prunus persica (L.) Batsch, Psidium sartorianum (O. Berg) Nied. and Stevia serrata Cav., for skin bumps Euphorbia pulcherrima Willd. ex Klotzsch, Ficus carica L., Illicium verum Hook. f. and Sida haenkeana C. Presl, for skin care Salvia leucantha Cav., for treating skin inflammation Aloysia citrodora Paláu, Artemisia ludoviciana Nutt., Artemisia mexicana Willd. ex Spreng., Eryngium beecheyanum Hook. f. \& Arn., Marrubium vulgare L. and Moringa oleifera Lam., and finally for superficial infections Argemone ochroleuca Sweet, Bursera bipinnata (DC.) Engl. and Eriobotrya japonica.

The literature review related to ethnopharmacological studies worldwide, focusing on dermatological conditions (96 published articles) and the information contained in the Digital Library of Traditional Mexican Medicine (Appendix), shows that several plants here reported $(91.25 \%)$ are used by other populations for treating skin affections. Additionally, this study provides new ethnopharmacological information about plants used for treating skin ailments in the study area, as well as at national and global level, as no ethnomedicinal reports were found for Eryngium beecheyanum, Tagetes remotiflora, Tournefortia mutabilis Vent., Equisetum hyemale L. var. affine (Engelm.) A.A. Eaton, Clinopodium macrostemum (Moc. \& Sessé ex Benth.) Kuntze, Salvia leucantha, Sida haenkeana and Urtica subincisa for managing dermatological conditions, which represent $8.25 \%$ of the reported plants (Appendix).

\section{DISCUSSION}

Mexico is considered one of the countries with the highest floristic richness in the world, only preceded by Brazil, 


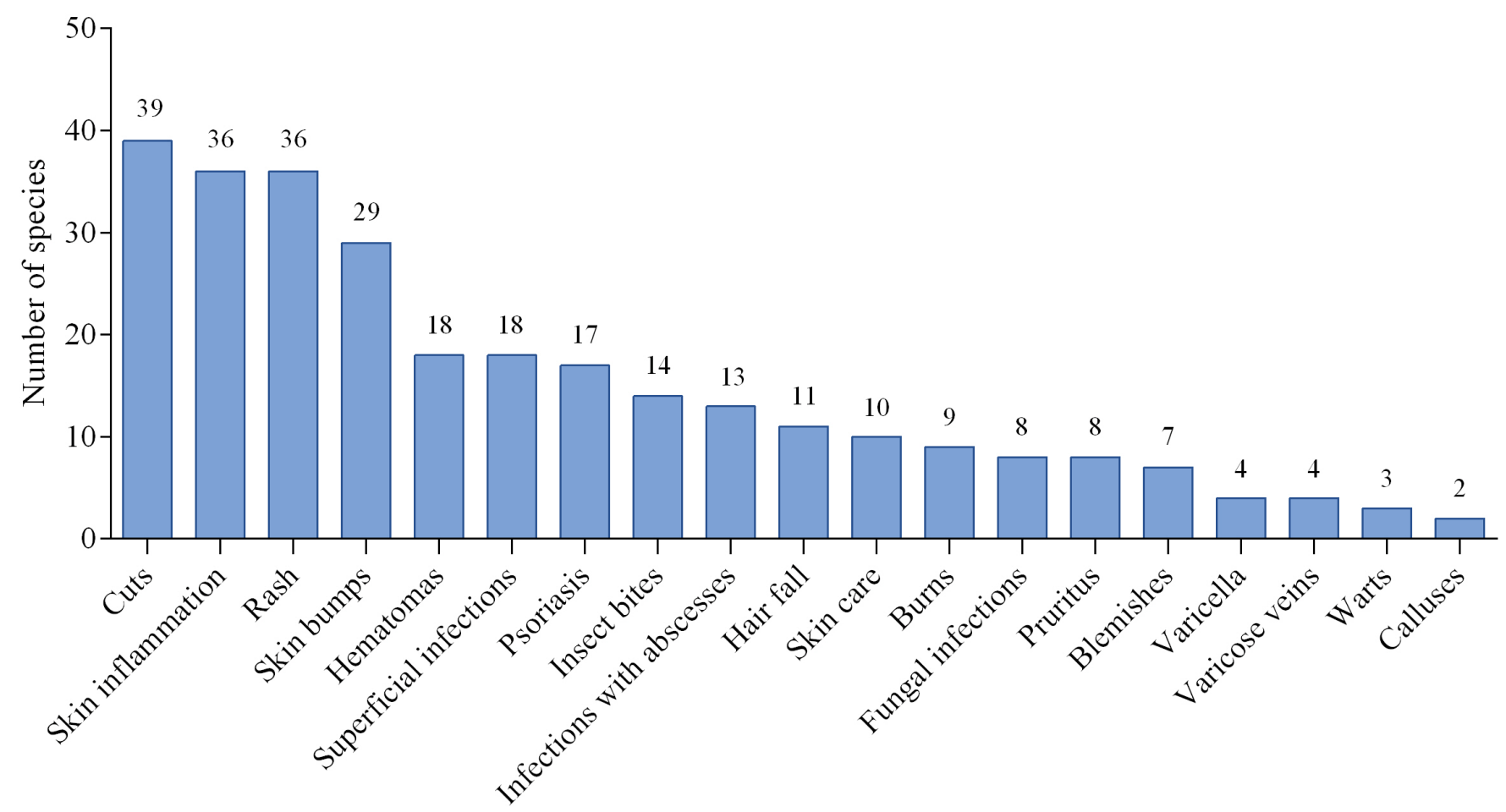

Dermatological conditions

Figure 4: Number of plant species used for treating dermatological conditions on the Purépecha Plateau.
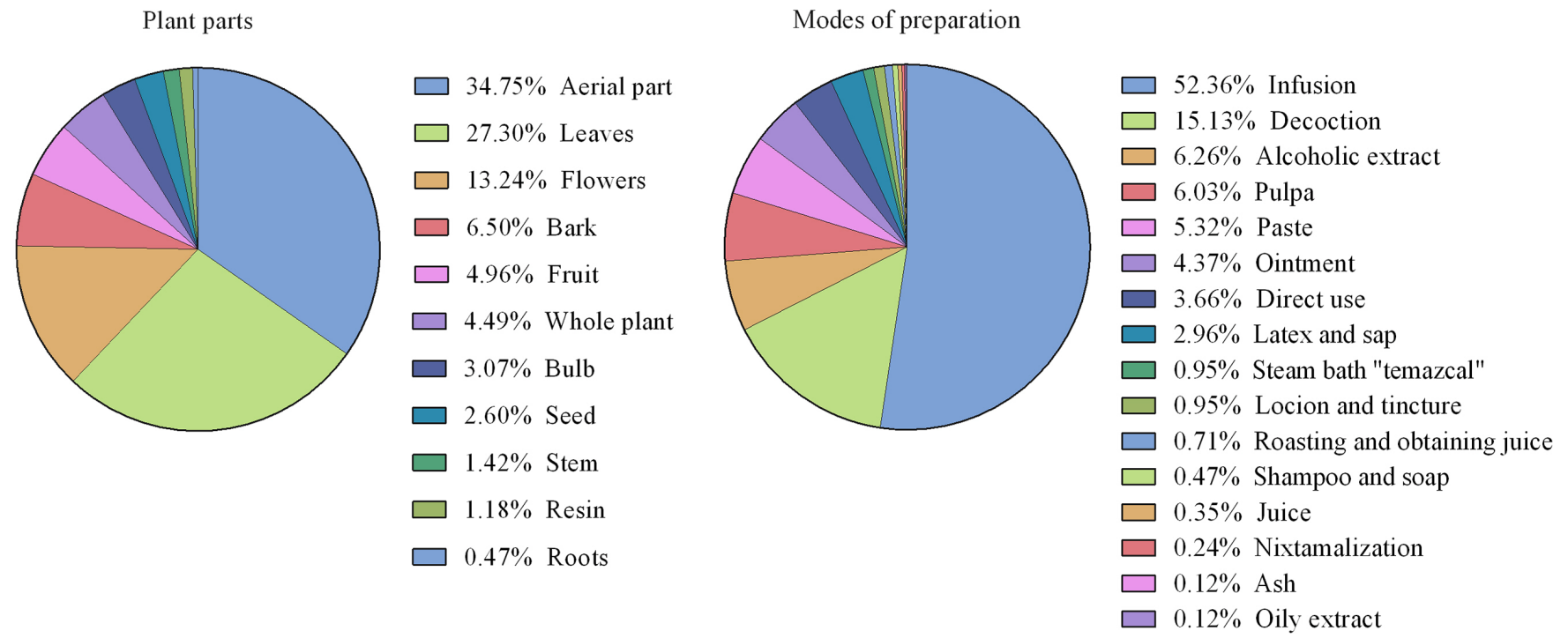

Figure 5: Plant parts and preparation modes used by inhabitants of the Purépecha Plateau for treating dermatological disorders. 


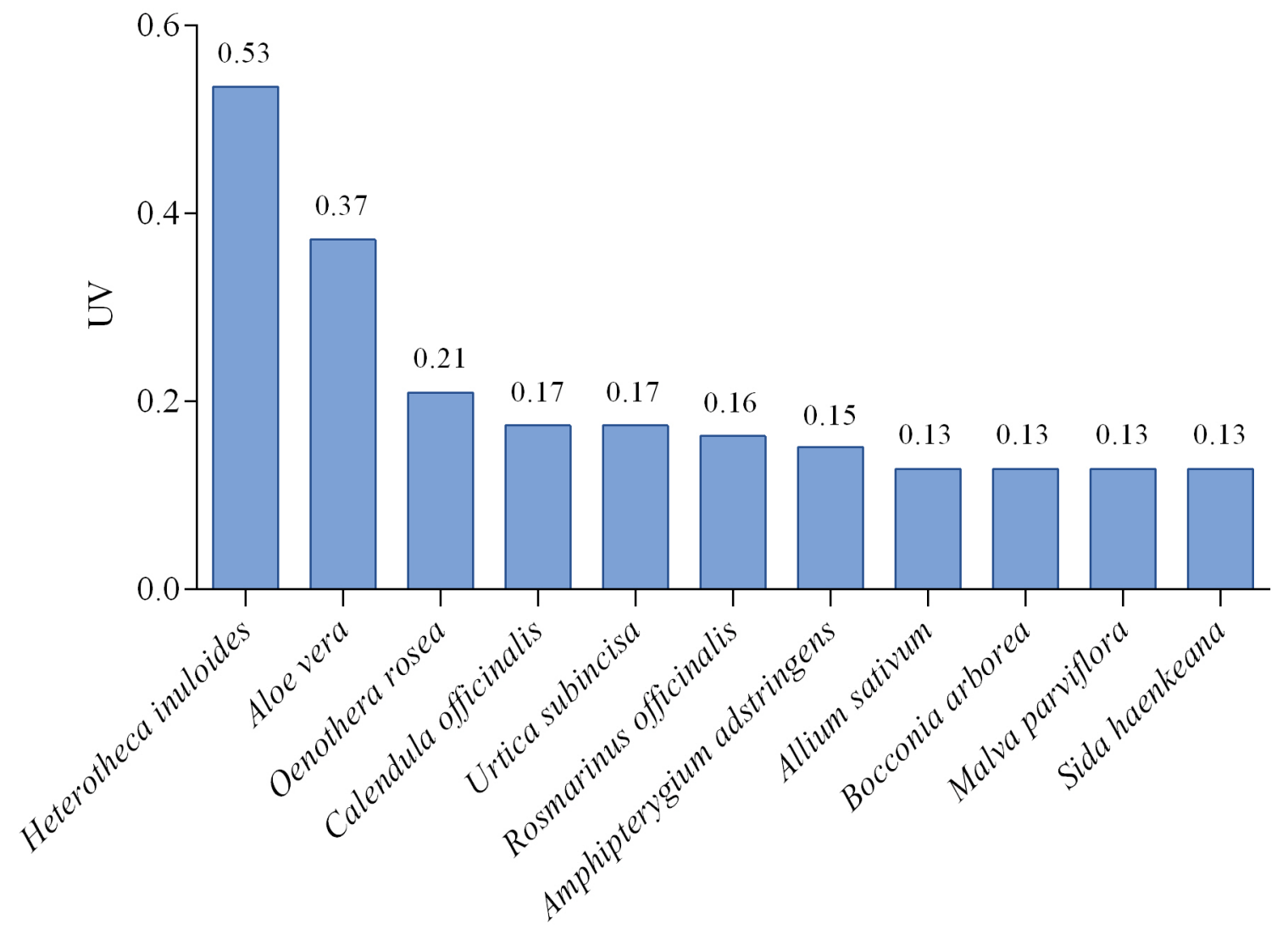

Figure 6: Plants with highest use values (UV) for treating dermatological ailments on the Purépecha Plateau.

China, Colombia and South Africa (Villaseñor, 2016). In this context, the study of ethnomedical systems, including the identification of herbal medicines, is of great importance in addressing health problems of traditional communities. On the Purépecha Plateau in the Mexican state of Michoacán, the knowledge about medicinal plants not only has an anthropological significance, it also allows that people with economic problems solve their health issues.

It is now recognized that the transmission of knowledge regarding the use of medicinal plants from old to new generations is declining (Calvo et al., 2011). This fact is also a reality in indigenous communities because of globalization and the use of orthodox medicine. Therefore, it is crucial to rescue this knowledge to prevent the loss of ethnomedical traditions, which is a precious scientific and cultural heritage for future generations.
The results indicate that among the inhabitants of the Purépecha Plateau, middle-aged people are the ones who best preserve the ethnopharmacological knowledge. It is suggested that there is a tendency towards the loss of these traditions among young persons of less than 30 years (Fig. 2). Juárez-Vázquez et al. (2013) noted that this is a common trend in Mexico. It is also striking that almost all knowledge about plants was obtained from women. This is related to the fact that based on the villager's recommendations, most of the contributors to this study were female. This was not unexpected, because it has been previously reported that among Purépechas, there is a clear quantitative predominance of women engaged in activities related to the use of medicinal plants (Gallardo Ruiz, 2002; BDMTM, 2009).

The present investigation has revealed the medicinal plants for treating skin affections and their modes of 
preparation on the Purépecha Plateau, Michoacán, Mexico. The most prominent families were Asteraceae, Lamiaceae and Solanaceae (Fig. 3). These results agree with a previous study performed in the indigenous community of Nuevo Parangaricutiro, a municipality of the Purépecha Plateau, which reported Asteraceae and Lamiaceae as the most important families used for medical purposes in this region (Bello-González and Salgado-Garciglia, 2013). Other ethnomedicinal studies performed in Mexico have also suggested that Asteraceae are an important source of medicinal plants in the country (Andrade-Cetto, 2009; Alonso-Castro et al., 2012), probably due to the high diversity of its phytochemical constituents.

The highest $F_{\text {ic }}$ values were linked with hematomas, skin inflammation, varicose veins and cuts, whereas lowest values were found for psoriasis and blemishes (Table 1). It is considered that higher values of this factor are related to prevalent illness in the region, which lead people to exchange information about their knowledge concerning plant therapy for a longer time (Gazzaneo et al., 2005). As previously mentioned, among dermatological conditions, a high morbidity has been reported in the state of Michoacán for venous insufficiency (100.88 per 100,000 population) and wounds (DGE, 2015), which could explain the higher values obtained for the consensus factor in these categories. Lower $\mathrm{F}_{\text {ic }}$ values for psoriasis and blemishes indicate that plants used for these ailments were chosen randomly or no information about them was exchanged among participants (Neamsuvan and Bunmee, 2016).

According to the information referred by the participants, the higher number of reported plants was used for treating cuts, skin inflammation and rash (Fig. 4). Literature review, regarding ethnopharmacological studies worldwide for dermatological conditions, also shows that many plants are used for cuts, in comparison with other skin ailments (Sharma et al., 2014; Neamsuvan and Bunmee, 2016). A recent study performed among the Zoque indigenous people of Chiapas and Oaxaca, Mexico, also found that among dermatological conditions, most plant remedies are used for wound treatment (Geck et al.,
2016). Another possible reason that could explain the preponderance of the use of plants in the region for cuts is the high incidence in Michoacán of morbidities associated with this ailment due to gunshots and dog bites (54.26 and 82.11 per 100,000 population respectively) (DGE, 2015).

Unexpectedly, some participants (mainly sellers and healers) referred during semi-structured interviews to the use of plants to treat specific diseases such as psoriasis (Fig. 4). Psoriasis is considered the second reason for dermatological consultation in Mexico (HGM-SSA, 2012). As it is an incurable disease, characterized by a low satisfaction of patients with treatments (García-Pérez et al., 2012), it is likely that the inhabitants of the Purépecha Plateau search natural alternatives for its treatment, leading to sellers and healers to know about this ailment. Unfortunately, no epidemiological studies were found about the incidence of this illness in this particular population.

For treating of dermatological disorders, the aerial parts were preferred by participants, followed by leaves and flowers (Fig. 5). This result agrees with previous studies which have reported the use of aerial parts to cure skin disorders due to their ease access in natural environments (Sharma et al., 2014; Neamsuvan and Bunmee, 2016). It is interesting to note that unlike other ethnopharmacological studies focusing on skin ailments (Njoroge and Bussmann, 2007; Abbasi et al., 2010; Afolayan et al., 2014; Sharma et al., 2014), Purépechas prefer the use of infusions and decoctions taken orally instead of topical administration, applying crushed plants, pastes and juices. This could be explained by the fact that among Purépechas there is a belief that dermatological disorders are manifestations of blood contamination (BDMTM, 2009). Therefore, they believe that cleansing the blood using herbal remedies by oral route would lead to improve skin problems. Another peculiar aspect to be highlighted is the fact that the population under study uses the "temazcal" $(0.95 \%)$ for the treatment of cutaneous conditions. This is a steam bath of pre-Hispanic origin used in Mexico for curative, preventive, hygienic and religious purposes (Aparicio Mena, 2006). Its use is supported by the belief that the heat of the patient's body is fundamental for hea- 
ling, since the disease is eliminated through sweat (BDMTM, 2009). The present study also reports the use of common salt in small proportions for the preparation of pastes. Additionally, Sharma et al. (2014) found the same trend in a study focusing on the use of herbal preparations for dermatological disorders in India. These authors argued that the possible reason behind the use of salt would be related with the fact that it inhibits the activity of bacteria and fungi, thereby helping the skin to heal (Sharma et al., 2014).

Native $(56.7 \%)$ and introduced (43.3\%) plants were valuable resources for local population for treating dermatological ailments (Appendix). Although in the context of medicinal plants, both introduced and native plants are important, it has been reported that in rural areas of Mexico, practitioners depend on the natural environment rather than cultivated areas to obtain medicinal plants (Andrade-Cetto, 2009; Alonso-Castro et al., 2012). Indeed, $53.6 \%$ of the collected plants of this study were gathered from the wild. The extensive use of native species by Purépechas could not only be related to a higher availability of these plants through the seasons, but also to the inherited knowledge about their medicinal properties from the ancestors. In fact, it is known that among Purépechas the transmission of knowledge related to traditional medicine is performed in more than $50 \%$ by means of relatives (BDMTM, 2009). However, a non-neglectable amount of exotic plants was also reported in the study area. The contribution of these species is very important as they amplify the spectrum of therapeutic alternatives for treating dermatological conditions on the Purépecha Plateau, reinforcing the local plant formulary.

Five plants with the highest UV to treat dermatological disorders on the Purépecha Plateau were Heterotheca inuloides, Aloe vera, Oenothera rosea, Calendula officinalis and Urtica subincisa (Fig. 6). Heterotheca inuloides is known as Mexican arnica and is extensively used for dermatological problems in Mexico. Additionally, this plant is used alone or in combination with other herbs, for diminishing the pain associated to rheumatism, stomach ulcers and other painful conditions associated with inflammatory processes. It is also reported in the management of kidney disease, urinary infections, cough, lung diseases, vaginal infections, gastrointestinal disorders and cancer (Rodríguez-Chávez et al., 2017).

According to the present study, Purépechas used this species for cuts, hematomas, infections with abscesses, skin inflammation, insect bites, rash, skin bumps, skin care, superficial infections, varicella, and varicose veins (Appendix). Its anti-inflammatory and antimicrobial properties in Purépecha traditional medicine are supported by pharmacological studies. Sesquiterpenes isolated from this plant exert activity against Bacillus subtilis var. niger Smith et al. (ATCC® 9372 ${ }^{\mathrm{TM}}$ ), Brevibacterium ammoniagenes (Cooke and Keith) Breed (ATCC $\AA$ 6872 ${ }^{\mathrm{TM}}$ ), Propionibacterium acnes (Gilchrist) Douglas and Gunter (ATCC ${ }^{\circledR} 11827^{\mathrm{TM}}$ ), Staphylococcus aureus subsp. aureus Rosenbach (ATCC ${ }^{\circledR} 12598^{\mathrm{TM}}$ ), Staphylococcus aureus subsp. aureus (ATCC ${ }^{\circledR} 33591^{\mathrm{TM}}$ ), Streptococcus mutans Clarke (ATCC ${ }^{\circledR} 25175^{\mathrm{TM}}$ ), and Trichophyton mentagrophytes (Robin) Blanchard (ATCC® $18748^{\mathrm{TM}}$ ) with minimal inhibitory concentrations ranged from 6.23 to 12.5 $\mathrm{mg} / \mathrm{mL}$ (Kubo et al., 1994). Infusions of Heterotheca inuloides inhibit the activity of cyclooxygenase enzyme by $40 \%$, suggesting an anti-inflammatory effect of polar metabolites of this plant (Muñoz-Velázquez et al., 2012).

Aloe vera has been widely used for treating skin diseases across the globe. This plant is also very popular for managing cutaneous conditions in other Mexican states, such as Oaxaca and Chiapas (Geck et al., 2016). Aloe vera has demonstrated pro-cicatrizing effects by increasing collagen content in wounds and the degree of collagen cross linking (Heggers et al., 1996). Additionally, it possesses a protective effect against skin damage induced by radiation, anti-inflammatory activity, moisturizing and anti-aging effects (Choi and Chung, 2003). These pharmacologic properties justify its extensive use in traditional Purépecha medicine. Oenothera rosea is a native plant of Mexico that stimulates the proliferation of normal human fibroblasts in vitro (Takahashi et al., 2012), which could be related to its use for cuts by Purépechas. This species also reduces chronic and acute skin inflammation in rats (Villena and Arro- 
yo, 2012), so it can function as anti-inflammatory agent, as referred by the population under study. Calendula officinalis has been employed in folk therapy for treating skin ailments worldwide. On the Purépecha Plateau, this plant is used for multiple skin affections including blemishes, burns, cuts, skin inflammation, insect bites, pruritus, psoriasis, rash, skin bumps and superficial infections (Appendix). Pharmacological studies suggest that extracts from this plant can protect skin against ultraviolet-induced damage (Fonseca et al., 2010). Moreover, this plant is highly effective for the prevention of acute dermatitis of grade 2 , which occurs after postoperative irradiation for breast cancer, demonstrating its anti-inflammatory properties (Pommier et al., 2004). The extract of the flowers of this plant is also broadly recognized by its wound-healing promoting effects (Preethi and Kuttan, 2011). The multiplicity of pharmacological activities of this species on the skin agrees with its wide use on the Purépecha Plateau for dermatological conditions. Surprisingly, Purépechas frequently reported the use of Urtica subincisa for skin inflammation, skin bumps and varicose veins (Appendix). To the best of our knowledge, this native plant has not been previously reported neither in Mexico nor in the world for treating cutaneous disorders. Further phytochemical, toxicological and pharmacological studies with this species are required to establish its importance for treating skin ailments.

Thirty-nine plants were the most important, according to their FL (100\%) for the treatment of 10 of the 19 dermatological conditions informed by the participants. These plants offer very interesting clues as to their pharmacological potential for the treatment of a specific skin ailment (Appendix). Additionally, this study provides new ethnopharmacological information about plants used for treating skin ailments on the Purépecha Plateau, Mexico and the world (Appendix). Apart from Tagetes remotiflora, all these plants are native of Mexico. Eryngium beecheyanum is a herbaceous plant which has been reported by peasants of the Sierra de Huautla, Morelos, Mexico, for kidney inflammation (Maldonado-Almanza, 1997). According to its fidelity level, it seems to be a promising candidate to treat skin inflammation $(\mathrm{FL}=100 \%)$. Tagetes remotiflora has been reported in the community of Nuevo Parangaricutiro by its antidiarrheic effect, as well as against vomiting, nerves and blood pressure (Bello-González et al., 2015). Its highest FL for cuts ( $F L=100 \%)$ indicates that it could also be employed for this affection. Tournefortia mutabilis has been reported to have antimicrobial properties (Sharma et al., 2017), which could be related to its use in superficial skin infections by Purépechas ( $\mathrm{FL}=66.7 \%$ ). In traditional Mexican medicine, Equisetum hyemale var. affine is mainly used for kidney conditions, pain, stomach inflammation, gastritis, ulcers and reproductive woman disorders (BDMTM, 2009). Although its use for treating skin conditions has not been reported, results obtained in this study indicate that it could probably be effective for hair fall and skin inflammation ( $\mathrm{FL}=50.0 \%$ ). Salvia leucantha is used in Mexico for stomach pain, respiratory ailments, reproductive disorders and diabetes (BDMTM, 2009; Romero-Cerecero et al., 2009). Our results point out that this species could also be used for skin care as the highest FL was obtained in this category. Although no reports were found regarding the use of Clinopodium macrostemum for dermatological disorders, its use for gastrointestinal affections and respiratory diseases has been documented in Mexico (INEGI, 2014). As its higher FL was obtained for skin inflammation ( $\mathrm{FL}=83.3 \%$ ), it would be interesting that further studies be performed to ratify this activity using in vitro and in vivo relevant models. To the best of our knowledge, Sida haenkeana and Urtica subincisa are reported for the first time as medicinal plants. According to their FL, Sida haenkeana seems to be a promising candidate to treat skin bumps $(\mathrm{FL}=100 \%)$, whereas Urtica subincisa was catalogued as anti-inflammatory agent $(\mathrm{FL}=80.0 \%)$. Traditional uses of the medicinal flora from the Purépecha Plateau can serve as a starting point for further scientific analysis, which may provide novel compounds or improved herbal preparations for treating skin diseases.

\section{CONCLUSIONS}

This study demonstrates that herbal remedies play an important role in healing skin by inhabitants of the Purépecha 
Plateau, state of Michoacán, Mexico. A total of 97 species were identified to treat 19 skin ailments. The quantitative analysis performed through the determination of the use value, fidelity level and the informant consensus factor allowed to identify plants as promising candidates for developing new dermatological formulations. This investigation is also a guide to the conservation of folk medicinal knowledge from indigenous people of Mexico, through a vision of sustainable use of natural resources. From the ethno-pharmacological point of view, it provides new information about plants whose medicinal properties for the skin had been unknown up to now. Additionally, it allows for dissemination of the inherited knowledge of $\mathrm{Pu}$ répechas regarding herbal preparations for cutaneous diseases. The identification of plants used by this population to treat skin pathologies also opens new perspectives for performing phytochemical, toxicological and pharmacological investigations that allow the development of new herbal preparations or new drugs addressed to improve the quality of life of patients suffering from these diseases.

\section{AUTHORS CONTRIBUTION}

MEGP, AOZ and REG designed the study. REG, MEGP and EPC conducted interviews and collected the plants referred by participants. EPC identified the specimens and deposited them in the herbarium IEB. REG drafted the manuscript under the supervision of AOZ, EPC and MEGP. All authors contributed to the review and approval of the final manuscript.

\section{FINANCING}

We thank the "Consejo Nacional de Ciencia y Tecnología" (CONACYT, Mexico) for the financial support of REG (Doctoral Fellowship).

\section{ACINNOWLEDGMENT}

The authors are very grateful to traditional healers, sellers and local inhabitants from the Purépecha Plateau for providing the valuable information regarding medicinal plants for skin ailments and kindly sharing their ancestral knowledge with us.

\section{LITERATURE CITED}

Abbasi, A. M., M. A. Khan, M. Ahmad, M. Zafar, S. Jahan and S. Sultana. 2010. Ethnopharmacological application of medicinal plants to cure skin diseases and in folk cosmetics among the tribal communities of North-West Frontier Province, Pakistan. Journal of Ethnopharmacology 128(2): 322-335. DOI: https://doi.org/10.1016/j.jep.2010.01.052

Acharya, E. and B. Pokhrel. 2006. Ethno-Medicinal plants used by Bantar of Bhaudaha, Morang, Nepal. Our Nature 4(1): 96-103. DOI: https://doi.org/10.3126/on.v4i1.508

Afolayan, A. J., D. S. Grierson and W. O. Mbeng. 2014. Ethnobotanical survey of medicinal plants used in the management of skin disorders among the Xhosa communities of the Amathole District, Eastern Cape, South Africa. Journal of Ethnopharmacology 153(1): 220-232. DOI: https://doi.org/10.1016/j.jep.2014.02.023

Akhtar, N., A. Rashid, W. Murad and E. Bergmeier. 2013. Diversity and use of ethno-medicinal plants in the region of Swat, North Pakistan. Journal of Ethnobiology and Ethnomedicine 9(1): 25. DOI: https://doi. org/10.1186/1746-4269-9-25

Al-Khalil, S. 1995. A survey of plants used in Jordanian traditional medicine. International Journal of Pharmacognosy 33(4): 317-323. DOI: https://doi. org/10.3109/13880209509065385

Alonso-Castro, A. J., J. J. Maldonado-Miranda, A. ZarateMartinez, M. R. Jacobo-Salcedo, C. Fernández-Galicia, L. A. Figueroa-Zuñiga, N. A. Rios-Reyes, M. A. de León-Rubio, N. A. Medellín-Castillo, A. Reyes-Munguia, R. Méndez-Martínez and C. Carranza-Álvarez. 2012. Medicinal plants used in the Huasteca Potosina, Mexico. Journal of Ethnopharmacology 143(1): 292-298. DOI: https://doi.org/10.1016/j.jep.2012.06.035

Amézcua Luna, J. and G. Sánchez Díaz. 2015. P’urhépecha. Comisión Nacional para el Desarrollo de los Pueblos Indígenas. México, D.F., México. Pp. 1-176.

Amiri, M. S. and M. R. Joharchi. 2013. Ethnobotanical investigation of traditional medicinal plants commercialized in the markets of Mashhad, Iran. Avicenna Journal of Phytomedicine 3(3): 254-271. DOI: https://doi.org/10.22038/ajp.2013.487 
Andrade-Cetto, A. 2009. Ethnobotanical study of the medicinal plants from Tlanchinol, Hidalgo, México. Journal of Ethnopharmacology 122(1): 163-171. DOI: https://doi. org/10.1016/j.jep.2008.12.008

Aparicio Mena, A. J. 2006. El temazcal en la cultura tradicional de salud y en la etnomedicina mesoamericana. Gazeta de Antropología 22: 1-11.

Augustin, M., B. Holland, D. Dartsch, A. Langenbruch and M. A. Radtke. 2011. Adherence in the treatment of psoriasis: a systematic review. Dermatology 222(4): 363-374. DOI: https://doi.org/10.1159/000329026

Ávila-Uribe, M. M., S. N. García-Zárate, A. S. SepúlvedaBarrera and M. A. Godínez-Rodríguez. 2016. Plantas medicinales en dos poblados del municipio de San Martín de las Pirámides, Estado de México. Polibotánica 42: 215 245. DOI: https://doi.org/10.18387/polibotanica.42.11

Balangcod, T. D. and A. K. D. Balangcod. 2011. Ethnomedical knowledge of plants and healthcare practices among the Kalanguya tribe in Tinoc, Ifugao, Luzon, Philippines. Indian Journal of Traditional Knowledge 10(2): 227-238.

Barrett, B. 1994. Medicinal plants of Nicaragua's Atlantic coast. Economic Botany 48(1): 8-20. DOI: https://doi. org/10.1007/BF02901375

BDMTM. 2009. Biblioteca Digital de la Medicina Tradicional Mexicana. Universidad Nacional Autónoma de México. México, D.F., México. http://www. medicinatradicionalmexicana.unam.mx/index.php (consulted November, 2017).

Bello-González, M. Á., S. Hernández-Muñoz, M. B. N. LaraChávez and R. Salgado-Garciglia. 2015. Plantas útiles de la comunidad indígena Nuevo San Juan Parangaricutiro, Michoacán, México. Polibotánica 39: 175-215. DOI: https://doi.org/10.18387/polibotanica.39.10

Bello-González, M. Á. and R. Salgado-Garciglia. 2013. Plantas medicinales de la comunidad indígena Nuevo San Juan Parangaricutiro, Michoacán, México. Biológicas 9(1): 126-138.

Benítez, G., M. R. González-Tejero and J. Molero-Mesa. 2010. Pharmaceutical ethnobotany in the western part of Granada province(southern Spain): ethnopharmacological synthesis. Journal of Ethnopharmacology 129(1): 87-105. DOI: https://doi.org/10.1016/j.jep.2010.02.016
Bhandary, M. J. and K. R. Chandrashekar. 2011. Herbal therapy for herpes in the ethno-medicine of Coastal Karnataka. Indian Journal of Traditional Knowledge 10(3): 528-532.

Bhardwaj, S. and S. K. Gakhar. 2005. Ethnomedicinal plants used by the tribals of Mizoram to cure cuts \& wounds. Indian Journal of Traditional Knowledge 4(2): 75-80.

Bhat, P., G. R. Hegde, G. Hegde and G. S. Mulgund. 2014. Ethnomedicinal plants to cure skin diseases-An account of the traditional knowledge in the coastal parts of Central Western Ghats, Karnataka, India. Journal of Ethnopharmacology 151(1): 493-502. DOI: https://doi. org/10.1016/j.jep.2013.10.062

BIOAGRICOOP. 1998. Bioagricoop México, A.C. Etnobotánica y herbolaria de la Meseta P'urepecha. http://bioagricoop.mx.tripod.com/etnobotanica.pdf (consulted November, 2017).

Cáceres, A., L. M. Girón, S. R. Alvarado and M. F. Torres. 1987. Screening of antimicrobial activity of plants popularly used in Guatemala for the treatment of dermatomucosal diseases. Journal of Ethnopharmacology 20(3): 223-237. DOI: https://doi.org/10.1016/0378-8741(87)90050-X

Calvo, M. I., S. Akerreta and R. Y. Cavero. 2011. Pharmaceutical ethnobotany in the Riverside of Navarra (Iberian Peninsula). Journal of Ethnopharmacology 135(1): 22-33. DOI: https://doi.org/10.1016/j.jep.2011.02.016

Cambell, L. 1997. American Indian Languages: The historical linguistics of Native America, Oxford Studies in Anthropological Linguistics. Oxford University Press. New York, USA. Pp. 1-528.

Canales-Martínez, M., T. Hernández-Delgado, C. FloresOrtiz, A. Durán-Díaz, A. M. García-Bores and G. ÁvilaAcevedo. 2005. Antimicrobial activity of Alternanthera caracasana. Pharmaceutical Biology 43(4): 305-307. DOI: https://doi.org/10.1080/13880200590951685

Caruana, U. and E. Attard. 2016. An ethno botanical survey of medicinal plants used in the Island of Gozo. Studies on Ethno-Medicine 10(2): 269-281. DOI: https://doi.org/10. 1080/09735070.2016.11905497

CDI. 2010. Cédulas de información básica de los pueblos indígenas de México. Comisión Nacional para el 
Desarrollo de los Pueblos Indígenas, México. http://www. cdi.gob.mx/cedulas/ (consulted November, 2017).

Chase, P. and O. P. Singh. 2013. Ethnomedicinal plants used by Angami tribe of Nagaland, India. Indian Journal of Tropical Biodiversity 21(1): 29-42.

Choi, S. and M.-H. Chung. 2003. A review on the relationship between Aloe vera components and their biologic effects. Seminars in Integrative Medicine 1(1): 53-62. DOI: https://doi.org/10.1016/S1543-1150(03)00005-X

Cuevas Figueroa, X. M. 2005. A revision of the genus Amphipterygium (Julianaceae). Ibugana 13(1): 27-47.

Dalgard, F. J., U. Gieler, L. Tomas-Aragones, L. Lien, F. Poot, G. B. E. Jemec, L. Misery, C. Szabo, D. Linder, F. Sampogna, A. W. M. Evers, J. A. Halvorsen, F. Balieva, J. Szepietowski, D. Romanov, S. E. Marron, I. K. Altunay, A. Y. Finlay, S. S. Salek and J. Kupfer. 2015. The psychological burden of skin diseases: a cross-sectional multicenter study among dermatological out-patients in 13 European countries. Journal of Investigative Dermatology 135(4): 984-991. DOI: https://doi. org/10.1038/jid.2014.530

Das, T., S. B. Mishra, D. Saha and S. Agarwal. 2012. Ethnobotanical survey of medicinal plants used by ethnic and rural people in Eastern Sikkim Himalayan region. African Journal of Basic \& Applied Sciences 4(1): 16-20.

De Feo, V., R. Aquino, A. Menghini, E. Ramundo and F. Senatore. 1992. Traditional phytotherapy in the Peninsula Sorrentina, Campania, southern Italy. Journal of Ethnopharmacology 36(2): 113-125. DOI: https://doi. org/10.1016/0378-8741(92)90010-O

DGE. 2015. Anuario de Morbilidad 2015. Dirección General de Epidemiología - Secretaría de Salud, México. http://www. epidemiologia.salud.gob.mx/anuario/html/anuarios.html (consulted November, 2017).

Egharevba, R. K. A. and M. I. Ikhatua. 2008. Ethno-medical uses of plants in the treatment of various skin diseases in Ovia North East, Edo State, Nigeria. Research Journal of Agriculture and Biological Science 4(1): 58-64.

El-Ghazali, G. E., K. S. Al-Khalifa, G. A. Saleem and E. M. Abdallah. 2010. Traditional medicinal plants indigenous to Al-Rass province, Saudi Arabia. Journal of Medicinal
Plants Research 4(24): 2680-2683. DOI: https://doi. org/10.5897/JMPR09.556

El Mansouri, L., A. Ennabili and D. Bousta. 2011. Interés socioeconómico y valorización de plantas medicinales del oasis de Rissani (SE de Marruecos). Boletín Latinoamericano y del Caribe de Plantas Medicinales y Aromáticas 10(1): 30-45.

Fernández, E. C., Y. E. Sandi and L. Kokoska. 2003. Ethnobotanical inventory of medicinal plants used in the Bustillo Province of the Potosi Department, Bolivia. Fitoterapia 74(4): 407-416. DOI: https://doi.org/10.1016/ S0367-326X(03)00053-4

Ferreira, F. S., S. V. Brito, S. C. Ribeiro, W. O. Almeida and R. R. N. Alves. 2009. Zootherapeutics utilized by residents of the community Poço Dantas, Crato-CE, Brazil. Journal of Ethnobiology and Ethnomedicine 5: 1-21. DOI: https:// doi.org/10.1186/1746-4269-5-21

Fonseca, Y. M., C. D. Catini, F. T. M. C. Vicentini, A. Nomizo, R. F. Gerlach and M. J. V. Fonseca. 2010. Protective effect of Calendula officinalis extract against UVB-induced oxidative stress in skin: evaluation of reduced glutathione levels and matrix metalloproteinase secretion. Journal of Ethnopharmacology 127(3): 596-601. DOI: https://doi. org/10.1016/j.jep.2009.12.019

Forgione, G., L. De Martino and V. De Feo. 2008. Medicinal plant in Samnium popular medicine. Pharmacology online 1: 90-98.

Frei, B., M. Baltisberger, O. Sticher and M. Heinrich. 1998. Medical ethnobotany of the Zapotecs of the Isthmus-Sierra (Oaxaca, Mexico): documentation and assessment of indigenous uses. Journal of Ethnopharmacology 62(2): 149-165. DOI: https://doi.org/10.1016/S03788741(98)00051-8

Gallardo Ruiz, J. 2002. Medicina tradicional P'urhépecha. El Colegio de Michoacán. Zamora, Michoacán, México. Pp. 1-342.

García-Pérez, M. E., J. Jean and R. Pouliot. 2012. Antipsoriatic drug development: challenges and new emerging therapies. Recent Patents on Inflammation \& Allergy Drug Discovery 6(1): 3-21. DOI: https://doi. org/10.2174/187221312798889248 
Gazzaneo, L. R. S., R. F. P. de Lucena and U. P. de Albuquerque. 2005. Knowledge and use of medicinal plants by local specialists in a region of Atlantic Forest in the state of Pernambuco (Northeastern Brazil). Journal of Ethnobiology and Ethnomedicine 1: 1-9. DOI: https://doi. org/10.1186/1746-4269-1-9

Gebrezgabiher, G., S. Kalayou and S. Sahle. 2013. An ethnoveterinary survey of medicinal plants in woredas of Tigray region, Northern Ethiopia. International Journal of Biodiversity and Conservation 5(2): 89-97.

Geck, M. S., A. J. Reyes García, L. Casu and M. Leonti. 2016. Acculturation and ethnomedicine: a regional comparison of medicinal plant knowledge among the Zoque of southern Mexico. Journal of Ethnopharmacology 187: 146-159. DOI: https://doi.org/10.1016/j.jep.2016.04.036

Gómez Aiza, A. 2013. Quemada: reproducción humana y enfermedades culturales en la sierra Otomí-Tepehua, Hidalgo. Estudios de Antropología Biológica 15(1): 273-313.

Grosso, L. 2010. El uso popular de las plantas medicinales en Uruguay: la experiencia de los pequeños productores agroecológicos. ZooBioDi - Associazione Italiana di Zootecnia Biologica e Biodinamica. Bergamo, Italia. Pp. $1-78$.

Guarrera, P. M. 2005. Traditional phytotherapy in Central Italy (Marche, Abruzzo, and Latium). Fitoterapia 76(1): 1-25. DOI: https://doi.org/10.1016/j.fitote.2004.09.006

Guarrera, P. M., G. Forti and S. Marignoli. 2005. Ethnobotanical and ethnomedicinal uses of plants in the district of Acquapendente (Latium, Central Italy). Journal of Ethnopharmacology 96(3): 429-444. DOI: https://doi. org/10.1016/j.jep.2004.09.014

Halberstein, R. A. 1997. Traditional botanical remedies on a small Caribbean island: Middle (Grand) Caicos, West Indies. Journal of Alternative and Complementary Medicine 3(3): 227-239. DOI: https://doi.org/10.1089/ acm.1997.3.227

Harsha, V. H., S. S. Hebbar, V. Shripathi and G. R. Hegde. 2003. Ethnomedicobotany of Uttara Kannada District in Karnataka, India-plants in treatment of skin diseases. Journal of Ethnopharmacology 84(1): 37-40. DOI: https:// doi.org/10.1016/S0378-8741(02)00261-1
Hay, R. J., N. E. Johns, H. C. Williams, I. W. Bolliger, R. P. Dellavalle, D. J. Margolis, R. Marks, L. Naldi, M. A. Weinstock, S. K. Wulf, C. Michaud, C. J. L. Murray and M. Naghavi. 2014. The global burden of skin disease in 2010: an analysis of the prevalence and impact of skin conditions. Journal of Investigative Dermatology 134(6): 1527-1534. DOI: https://doi.org/10.1038/jid.2013.446

Heggers, J. P., A. Kucukcelebi, D. Listengarten, J. Stabenau, F. Ko, L. D. Broemeling, M. C. Robson and W. D. Winters. 1996. Beneficial effect of Aloe on wound healing in an excisional wound model. Journal of Alternative and Complementary Medicine 2(2): 271-277. DOI: https:// doi.org/10.1089/acm.1996.2.271

Heinrich, M. and S. Gibbons. 2001. Ethnopharmacology in drug discovery: an analysis of its role and potential contribution. Journal of Pharmacy and Pharmacology 53(4): 425-432. DOI: https://doi.org/10.1211/0022357011775712

HGM-SSA. 2012. Boletín estadístico de dermatología 20022011. Hospital General de México-Secretaría de Salud. México, D.F., México. http://www.hgm.salud.gob.mx/ descargas/pdf/planeacion/boletin_derma_02_11.pdf (consulted November, 2017).

Hurtado-Rico, N. E., C. Rodríguez-Jiménez and A. AguilarContreras. 2006. Estudio cualitativo y cuantitativo de la flora medicinal del municipio de Copándaro de Galeana, Michoacán, México. Polibotánica 22: 21-50.

Ijaz, F., Z. Iqbal, I. U. Rahman, J. Alam, S. M. Khan, G. M. Shah, K. Khan and A. Afzal. 2016. Investigation of traditional medicinal floral knowledge of Sarban Hills, Abbottabad, KP, Pakistan. Journal of Ethnopharmacology 179: 208233. DOI: https://doi.org/10.1016/j.jep.2015.12.050

INEGI. 2014. Sistema de consulta de especies y productos agropecuarios, forestales y pesqueros. Instituto Nacional de Estadística y Geografía. http://www.inegi.org.mx/ est/contenidos/proyectos/aspectosmetodologicos/ clasificadoresycatalogos/catalogo_especies.aspx (consulted November, 2017).

INEGI. 2004. La población hablante de lengua indígena de Michoacán de Ocampo. Instituto Nacional de Estadística y Geografía e Informática. Aguascalientes, México. Pp. $1-140$ 
Jarić, S., Z. Popović, M. Mačukanović-Jocić, L. Djurdjević, M. Mijatović, B. Karadžić, M. Mitrović and P. Pavlović. 2007. An ethnobotanical study on the usage of wild medicinal herbs from Kopaonik Mountain (Central Serbia). Journal of Ethnopharmacology 111(1): 160-175. DOI: https://doi. org/10.1016/j.jep.2006.11.007

Jiofack, T., C. Fokunang, V. Kemeuze, E. Fongnzossie, N. Tsabang, R. Nkuinkeu, P. M. Mapongmetsem and B. A. Nkongmeneck. 2008. Ethnobotany and phytopharmacopoea of the South-West ethnoecological region of Cameroon. Journal of Medicinal Plants Research 2(8): 197-206.

Joshi, A. R. and K. Joshi. 2000. Indigenous knowledge and uses of medicinal plants by local communities of the Kali Gandaki Watershed Area, Nepal. Journal of Ethnopharmacology 73(1-2): 175-183. DOI: https://doi. org/10.1016/S0378-8741(00)00301-9

Juárez-Vázquez, M. C., C. Carranza-Álvarez, A. J. AlonsoCastro, V. F. González-Alcaraz, E. Bravo-Acevedo, F. J. Chamarro-Tinajero and E. Solano. 2013. Ethnobotany of medicinal plants used in Xalpatlahuac, Guerrero, Mexico. Journal of Ethnopharmacology 148(2): 521-527. DOI: https://doi.org/10.1016/j.jep.2013.04.048

Kala, C. P. 2005. Ethnomedicinal botany of the Apatani in the Eastern Himalayan region of India. Journal of Ethnobiology and Ethnomedicine 1: 11. DOI: https://doi. org/10.1186/1746-4269-1-11

Kamatenesi-Mugisha, M., H. Oryem-Origa, O. Odyek and D. W. Makawiti. 2008. Medicinal plants used in the treatment of fungal and bacterial infections in and around Queen Elizabeth Biosphere Reserve, western Uganda. African Journal of Ecology 46(s1): 90-97. DOI: https:// doi.org/10.1111/j.1365-2028.2008.00935.x

Kasolo, J. N., G. S. Bimenya, L. Ojok, J. Ochieng and J. W. Ogwal-okeng. 2010. Phytochemicals and uses of Moringa oleifera leaves in Ugandan rural communities. Journal of Medicinal Plants Research 4(9): 753-757.

Khabbach, A., M. Libiad, A. Ennabili and D. Bousta. 2012. Medicinal and cosmetic use of plants from the province of Taza, Northern Morocco. Boletín Latinoamericano y del Caribe de Plantas Medicinales y Aromáticas 11(1): 46-60.
Kinghorn, A. D. 2001. Stevia: The genus Stevia. Taylor \& Francis Inc. New York, USA. Pp. 1-202.

Kubo, I., H. Muroi, A. Kubo, S. K. Chaudhuri, Y. Sanchez and T. Ogura. 1994. Antimicrobial agents from Heterotheca inuloides. Planta Medica 60(3): 218-221. DOI: https:// doi.org/10.1055/s-2006-959462

Lal, B. and K. N. Singh. 2008. Indigenous herbal remedies used to cure skin disorders by the natives of LahaulSpiti in Himachal Pradesh. Indian Journal of Traditional Knowledge 7(2): 237-241.

Lans, C. 2007. Comparison of plants used for skin and stomach problems in Trinidad and Tobago with Asian ethnomedicine. Journal of Ethnobiology and Ethnomedicine 3: 3. DOI: https://doi.org/10.1186/17464269-3-3

Leporatti, M. L. and P. M. Guarrera. 2007. Ethnobotanical remarks in Capitanata and Salento areas (Puglia, Southern Italy). Etnobiología 5(1): 51-64.

Lev, E. 2006. Ethno-diversity within current ethnopharmacology as part of Israeli traditional medicine - A review. Journal of Ethnobiology and Ethnomedicine 2: 4. DOI: https://doi.org/10.1186/1746-4269-2-4

Luna-José, A. L., L. Montalvo-Espinosa and B. RendónAguilar. 2003. Los usos no leñosos de los encinos en México. Boletín de la Sociedad Botánica de México 72: 107-117.

Mahbubur Rahman, A. H. M., S. Akter, R. Rani and A. K. M Rafiul Islam. 2015. Taxonomic study of leafy vegetables at Santahar Pouroshova of District Bogra, Bangladesh with emphasis on medicinal plants. International Journal of Advanced Research 3(5): 1019-1036.

Maiza, K., V. Hammiche and F. Maiza-Benabdesselam. 2011. Traditional medicine in North Sahara: the "deff". Life Sciences Leaflets 16: 551-560.

Maldonado-Almanza, B. J. 1997. Aprovechamiento de los recursos florísticos de la Sierra de Huautla, Morelos, México. Tesis de maestría. Facultad de Ciencias, Universidad Nacional Autónoma de México. México, D.F., México. Pp. 1-149.

Malla, B. and R. B. Chhetri. 2009. Indigenous knowledge on ethnobotanical plants of Kavrepalanchowk District. 
Kathmandu University Journal of Science, Engineering and Technology 5(2): 96-109.

Manzur-ul-Kadir Mia, M., M. Fahim Kadir, M. Shahadat Hossan and M. Rahmatullah. 2009. Medicinal plants of the Garo tribe inhabiting the Madhupur forest region of Bangladesh. American-Eurasian Journal of Sustainable Agriculture 3(2): 165-171.

Martínez, G. J. and G. E. Barboza. 2010. Natural pharmacopoeia used in traditional Toba medicine for the treatment of parasitosis and skin disorders (Central Chaco, Argentina). Journal of Ethnopharmacology 132(1): 86-100. DOI: https://doi.org/10.1016/j.jep.2010.07.049

Medina, C. 2003. La flora: riqueza, diversidad y sus relaciones fitogeográficas. In: Velázquez, A., A. Torres and G. Bocco (eds.). Las Enseñanzas de San Juan. Instituto Nacional de Ecología-Secretaría de Medio Ambiente y Recursos Naturales. México, D.F., México. Pp. 165-200.

Mercado-Vargas, H. and M. Palmerín Cerna. 2012. El Estado de Michoacán y sus regiones turísticas. Fundación Universitaria Andaluza Inca Garcilaso. Málaga, España. Pp. 1-139.

Mollik, M. A. H., M. S. Hossan, A. K. Paul, M. TaufiqUr-Rahman, R. Jahan and M. Rahmatullah. 2010. A comparative analysis of medicinal plants used by folk medicinal healers in three districts of Bangladesh and inquiry as to mode of selection of medicinal plants. Ethnobotany Research and Applications 8: 195-218. DOI: https://doi.org/10.17348/era.8.0.195-218

Monroy-Ortiz, C., E. García-Moya, A. Romero-Manzanares, C. Sánchez-Quintanar, M. Luna-Cavazos, E. UscangaMortera, J. S. Flores-Guido and V. González-Romero. 2013. Plants of local interest for medicinal and conservation purposes in Morelos, Mexico. Studies on Ethno-Medicine 7(1): 13-26. DOI: https://doi.org/10.108 0/09735070.2013.11886443

Monzote, L., M. García, A. A. Montalvo, R. Linares and R. Scull. 2009. Effect of oral treatment with the essential oil from Chenopodium ambrosioides against cutaneous leishmaniasis in BALB/c mice, caused by Leishmania amazonensis. Research in Complementary Medicine 16(5): 334-338. DOI: https://doi.org/10.1159/000237741
Muñoz-Velázquez, E. E., K. Rivas-Díaz, M. G. F. Loarca-Piña, S. Mendoza-Díaz, R. Reynoso-Camacho and M. RamosGómez. 2012. Comparación del contenido fenólico, capacidad antioxidante y actividad antiinflamatoria de infusiones herbales comerciales. Revista Mexicana de Ciencias Agrícolas 3(3): 481-495.

Nath, M. and M. D. Choudhury. 2010. Ethno-medico-botanical aspects of Hmar tribe of Cachar district, Assam (Part I). Indian Journal of Traditional Knowledge 9(4): 760-764.

Navarrete-Heredia, J. L. and V. H. GómezFlores. 2005. Aspectos etnoentomológicos acerca de Paederus sp. (Coleoptera: Stanphylinidae) en Mascota, Jalisco, México. Dugesiana 12(1): 9-18.

Navarro Pérez, L. C. and S. Avendaño Reyes. 2002. Flora útil del municipio de Astacinga, Veracruz, México. Polibotánica 14: 67-84.

Navarro, V., M. L. Villarreal, G. Rojas and X. Lozoya. 1996. Antimicrobial evaluation of some plants used in Mexican traditional medicine for the treatment of infectious diseases. Journal of Ethnopharmacology 53(3): 143-147. DOI: https://doi.org/10.1016/0378-8741(96)01429-8

Neamsuvan, O. and P. Bunmee. 2016. A survey of herbal weeds for treating skin disorders from Southern Thailand: Songkhla and Krabi Province. Journal of Ethnopharmacology 193: 574-585. DOI: https://doi. org/10.1016/j.jep.2016.09.048

Nicholson, M. S. 1991. The market medicinal plants of Monterrey, Nuevo León, Mexico. Master Thesis. Eastern Illinois University. Illinois, USA. Pp. 1-188.

Njoroge, G. N. and R. W. Bussmann. 2007. Ethnotherapeutic management of skin diseases among the Kikuyus of Central Kenya. Journal of Ethnopharmacology 111(2): 303-307. DOI: https://doi.org/10.1016/j.jep.2006.11.025

Okuma, C. H., A. M. Pereira, A. L. P. de Souza, F. M. Tasca, J. V. Visentainer, J. Mazucheli, J. C. Palazzo de Mello, T. Ueda-Nakamura, B. P. Dias-Filho and C. V. Nakamura. 2011. In vitro melanogenic activity of Macadamia integrifolia oil and clinical pilot study of a pharmaceutical formulation in patients with vitiligo. Latin American Journal of Pharmacy 30(7): 1336-1341. 
Oliveira, D. F., A. C. Pereira, H. C. P. Figueiredo, D. A. Carvalho, G. Silva, A. S. Nunes, D. S. Alves and H. W. P. Carvalho. 2007. Antibacterial activity of plant extracts from Brazilian southeast region. Fitoterapia 78(2): 142145. DOI: https://doi.org/10.1016/j.fitote.2006.09.027

Ong, H. C. and M. Nordiana. 1999. Malay ethno-medico botany in Machang, Kelantan, Malaysia. Fitoterapia 70(5): 502-513. DOI: https://doi.org/10.1016/S0367326X(99)00077-5

Ong, H. C., R. M. Zuki and P. Milow. 2011. Traditional knowledge of medicinal plants among the Malay Villagers in Kampung Mak Kemas, Terengganu, Malaysia. Studies on Ethno-Medicine 5(3): 175-185. DOI: https://doi.org/1 $0.1080 / 09735070.2011 .11886407$

Orduña Trejo, C., A. Castro Campillo and J. Ramírez Pulido. 1999. Mammals from the Tarascan Plateau, Michoacán, México. Revista Mexicana de Mastozoología 4(1): 53-68.

Ouhaddou, H., H. Boubaker, F. Msanda and A. El Mousadik. 2015. An ethnobotanical study of medicinal plants of the Agadir Ida Ou Tanane province (southwest Morocco). Journal of Applied Biosciences 84(1): 7707-7722. DOI: https://doi.org/10.4314/jab.v84i1.5

Paek, S. Y., A. Koriakos, S. Saxton-Daniels and A. G. Pandya. 2012. Skin diseases in rural Yucatán, Mexico. International Journal of Dermatology 51(7): 823-828. DOI: https://doi. org/10.1111/j.1365-4632.2011.05190.x

Palmese, M. T., R. E. Uncini Manganelli and P. E. Tomei. 2001. An ethno-pharmacobotanical survey in the Sarrabus district (south-east Sardinia). Fitoterapia 72(6): 619-643. DOI: https://doi.org/10.1016/S0367-326X(01)00288-X

Panda, A. and M. K. Misra. 2011. Ethnomedicinal survey of some wetland plants of South Orissa and their conservation. Indian Journal of Traditional Knowledge 10(2): 296-303.

Parvez Rana, M., M. Shawkat Islam Sohel, S. Akhter and M. Jahirul Islam. 2010. Ethno-medicinal plants use by the Manipuri tribal community in Bangladesh. Journal of Forestry Research 21(1): 85-92. DOI: https://doi. org/10.1007/s11676-010-0015-1

Pascual, L. M. 1994. Estudios etnobotánicos en la provincia de Castellón. Natura Medicatrix 37: 22-29.
Pieroni, A. and M. E. Giusti. 2008. The remedies of the folk medicine of the Croatians living in Ćićarija, Northern Istria. Collegium Antropologicum 32(2): 623-627.

Pieroni, A., M. E. Giusti, H. Münz, C. Lenzarini, G. Turković and A. Turković. 2003. Ethnobotanical knowledge of the Istro-Romanians of Žejane in Croatia. Fitoterapia 74(7-8): 710-719. DOI: https://doi.org/10.1016/j. fitote.2003.06.002

Policepatel, S. S. and V. G. Manikrao. 2013. Ethnomedicinal plants used in the treatment of skin diseases in Hyderabad Karnataka region, Karnataka, India. Asian Pacific Journal of Tropical Biomedicine 3(11): 882-886. DOI: https://doi. org/10.1016/S2221-1691(13)60173-2

Pollio, A., A. De Natale, E. Appetiti, G. Aliotta and A. Touwaide. 2008. Continuity and change in the Mediterranean medical tradition: Ruta spp. (Rutaceae) in Hippocratic medicine and present practices. Journal of Ethnopharmacology 116(3): 469-482. DOI: https://doi. org/10.1016/j.jep.2007.12.013

Pommier, P., F. Gomez, M. P. Sunyach, A. D'Hombres, C. Carrie and X. Montbarbon. 2004. Phase III randomized trial of Calendula officinalis compared with trolamine for the prevention of acute dermatitis during irradiation for breast cancer. Journal of Clinical Oncology 22(8): 14471453. DOI: https://doi.org/10.1200/JCO.2004.07.063

Prashantkumar, P. and G. M. Vidyasagar. 2008. Traditional knowledge on medicinal plants used for the treatment of skin diseases in Bidar district, Karnataka. Indian Journal of Traditional Knowledge 7(2): 273-276.

Preethi, K. C. and R. Kuttan. 2011. Wound healing activity of flower extract of Calendula officinalis. Journal of Basic and Clinical Physiology and Pharmacology 20(1): 73-80. DOI: https://doi.org/10.1515/JBCPP.2009.20.1.73

Priya, K. and S. Sharma. 2014. Ethno-botanical importance of some tree species in Jammu District, J\&K. International Journal of Science and Research 3(11): 2795-2798.

Ramya, S., C. Rajasekaran, R. Sivaperumal, A. Krishnan and R. Jayakumararaj. 2008. Ethnomedicinal perspectives of botanicals used by Malayali Tribes in Vattal Hills of Dharmapuri (TN), India. Ethnobotanical Leaflets 12: 1054-1060. 
Regassa, R. 2013. Assessment of indigenous knowledge of medicinal plant practice and mode of service delivery in Hawassa city, southern Ethiopia. Journal of Medicinal Plants Research 7(9): 517-535. DOI: https://doi. org/10.5897/JMPR12.1126

Rexhepi, B., B. Mustafa, A. Hajdari, J. Rushidi-Rexhepi, C. L. Quave and A. Pieroni. 2013. Traditional medicinal plant knowledge among Albanians, Macedonians and Gorani in the Sharr Mountains (Republic of Macedonia). Genetic Resources and Crop Evolution 60(7): 2055-2080. DOI: https://doi.org/10.1007/s10722-013-9974-3

Rodríguez-Chávez, J. L., V. Egas, E. Linares, R. Bye, T. Hernández, F. J. Espinosa-García and G. Delgado. 2017. Mexican arnica (Heterotheca inuloides Cass. Asteraceae: Astereae): ethnomedical uses, chemical constituents and biological properties. Journal of Ethnopharmacology 195: 39-63. DOI: https://doi.org/10.1016/j.jep.2016.11.021

Romero-Cerecero, O., H. Reyes-Morales, L. AguilarSantamaría, M. Huerta-Reyes and J. Tortoriello-García. 2009. Use of medicinal plants among patients with Diabetes mellitus type 2 in Morelos, Mexico. Boletín Latinoamericano y del Caribe de Plantas Medicinales y Aromáticas 8(5): 380-388.

Sabeen, M. and S. S. Ahmad. 2009. Exploring the folk medicinal flora of Abbotabad City, Pakistan. Ethnobotanical Leaflets 13: $810-833$.

Sarma, S. K. and M. Saikia. 2010. Utilization of wetland resources by the rural people of Nagaon district, Assam. Indian Journal of Traditional Knowledge 9(1): 145-151.

Shah, B., F. Sheth and M. Parabia. 2011. Documenting Grandmas' prescriptions for skin ailments in Valsad district, Gujarat. Indian Journal of Traditional Knowledge 10(2): 372-374.

Sharma, A., R. D. C. Flores-Vallejo, A. Cardoso-Taketa and M. L. Villarreal. 2017. Antibacterial activities of medicinal plants used in Mexican traditional medicine. Journal of Ethnopharmacology 208: 264-329. DOI: https://doi. org/10.1016/j.jep.2016.04.045

Sharma, J., S. Gairola, Y. P. Sharma and R. D. Gaur. 2014. Ethnomedicinal plants used to treat skin diseases by Tharu community of district Udham Singh Nagar, Uttarakhand,
India. Journal of Ethnopharmacology 158(Part A): 140206. DOI: https://doi.org/10.1016/j.jep.2014.10.004

Silja, V.P., K. S. Varma and K. V. Mohanan. 2008. Ethnomedicinal plant knowledge of the Mullu kuruma tribe of Wayanad district, Kerala. Indian Journal of Traditional Knowledge 7(4): 604-612.

Singh, K. K. 1997. Studies on native medicine of Jaunsari Tribe of Dehradun District, Uttar Pradesh, India. International Journal of Pharmacognosy 35(2): 105-110. DOI: https:// doi.org/10.1076/phbi.35.2.105.13289

Storm, A., E. Benfeldt, S. E. Andersen and J. Serup. 2008. A prospective study of patient adherence to topical treatments: $95 \%$ of patients underdose. Journal of the American Academy of Dermatology 59(6): 975-980. DOI: https://doi.org/10.1016/j.jaad.2008.07.039

Tahvilian, R., S. Shahriari, A. Faramarzi and A. Komasi. 2014. Ethno-pharmaceutical formulations in Kurdish ethnomedicine. Iranian Journal of Pharmaceutical Research 13(3): 1029-1039.

Takahashi, M., Y. Asikin, K. Takara and K. Wada. 2012. Screening of medicinal and edible plants in Okinawa, Japan, for enhanced proliferative and collagen synthesis activities in NB1RGB human skin fibroblast cells. Bioscience, Biotechnology, and Biochemistry 76(12): 2317-2320. DOI: https://doi.org/10.1271/bbb.120478

Tolossa, K., E. Debela, S. Athanasiadou, A. Tolera, G. Ganga and J. G. Houdijk. 2013. Ethno-medicinal study of plants used for treatment of human and livestock ailments by traditional healers in South Omo, Southern Ethiopia. Journal of Ethnobiology and Ethnomedicine 9: 32. DOI: https://doi.org/10.1186/1746-4269-9-32

Torri, M. C. 2013. A medicina tradicional na América do Sul e as relações complexas entre os valores culturais, espirituais e terapêuticos das plantas. Revista de Geografia (Recife) 30(3): 6-23.

Uddin, M. Z., M. A. Hassan, M. Rahman and K. Arefin. 2012. Ethno-medico-botanical study in Lawachara National Park, Bangladesh. Bangladesh Journal of Botany 41(1): 97-104. DOI: https://doi.org/10.3329/bjb.v41i1.11087

Ugulu, I. 2012. Fidelity level and knowledge of medicinal plants used to make Therapeutic Turkish Baths. Studies 
on Ethno-Medicine 6(1): 1-9. DOI: https://doi.org/10.108 $0 / 09735070.2012 .11886413$

Van der Nat, J. M., W. G. van der Sluis, K. T. D de Silva and R. P. Labadie. 1991. Ethnopharmacognostical survey of Azadirachta indica A. Juss (Meliaceae). Journal of Ethnopharmacology 35(1): 1-24. DOI: https://doi. org/10.1016/0378-8741(91)90131-V

Villaseñor, J. L. 2016. Checklist of the native vascular plants of Mexico. Revista Mexicana de Biodiversidad 87(3): 559902. DOI: https://doi.org/10.1016/j.rmb.2016.06.017

Villena, C. A. and J. L. Arroyo. 2012. Efecto antiinflamatorio del extracto hidroalcohólico de Oenothera rosea (yawar socco) en ratas con inducción a la inflamación aguda y crónica. Ciencia e Investigación 15(1): 15-19.

Vivekraj, P. and V. Anandgideon. 2015. Medico-ethno botany: a survey of Topsengattupatti Pachamalai Hills of eastern ghats in Tamilnadu, South India. Advances in Applied Science Research 6(12): 59-63.

Zacchino, S., M. G. Derita and M. J. Svetaz. 2012. Discovery of antifungal plants in Argentinean San Luis Province: ethnomedical information or random selection? Revista Eletrônica de Farmácia 9(1): 18-39. DOI: https://doi. org/10.5216/ref.v9i1.17775 


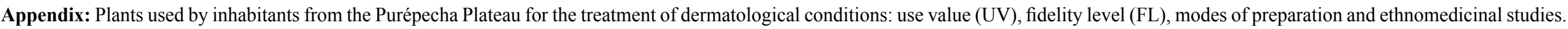

\begin{tabular}{|c|c|c|c|c|c|c|}
\hline $\begin{array}{l}\text { Scientific name (voucher specimen number } \\
\text { in the herbarium IEB) }\end{array}$ & Vernacular name & $\begin{array}{c}\text { Native plant } \\
\text { of Mexico }\end{array}$ & $\begin{array}{l}\text { Use Value/Dermatological } \\
\text { conditions (fidelity level) }\end{array}$ & $\begin{array}{l}\text { Mode of preparation by inhabitants } \\
\text { from the Purépecha Plateau }\end{array}$ & $\begin{array}{l}\text { Ethnomedicinal studies worldwide } \\
\text { mentioning the use of the species for } \\
\text { dermatological conditions }\end{array}$ & References \\
\hline \multicolumn{7}{|l|}{ PTERIDOPHYTA } \\
\hline \multicolumn{7}{|l|}{ Pteridaceae } \\
\hline Adiantum capillus-veneris L. (256871) & cilantrillo & yes & $\begin{array}{l}0.03 / \text { rash }(66.7) \\
\text { skin bumps }(66.7)\end{array}$ & $\begin{array}{l}\text { The infusion of the whole plant is used } \\
\text { for washing the affected area. }\end{array}$ & $\begin{array}{l}\text { North-West Frontier Province, Pakistan, } \\
\text { for measles treatment. }\end{array}$ & Abbasi et al., 2010. \\
\hline \multicolumn{7}{|l|}{ GYMNOSPERMAE } \\
\hline \multicolumn{7}{|l|}{ Pinaceae } \\
\hline $\begin{array}{l}\text { Pinus leiophylla Schiede ex Schltdl. \& } \\
\text { Cham. (256882) }\end{array}$ & pino & yes & $\begin{array}{l}0.05 / \text { skin inflammation } \\
(75), \text { hematomas }(25), \\
\text { psoriasis (25), skin bumps } \\
(25)\end{array}$ & $\begin{array}{l}\text { The alcoholic extract of its bark is } \\
\text { used in fomentation form on the } \\
\text { affected area. The oil obtained from } \\
\text { the distillation of its resin is used to } \\
\text { prepare ointments. }\end{array}$ & Mexico, for treating dermatitis. & BDMTM, 2009. \\
\hline \multicolumn{7}{|l|}{ ANGIOSPERM } \\
\hline \multicolumn{7}{|l|}{ Acanthaceae } \\
\hline Justicia spicigera Schltdl. (256899) & muicle & yes & $\begin{array}{l}0.12 \text { /skin inflammation } \\
(50), \text { rash (30), blemishes } \\
(20), \text { insect bites (20), } \\
\text { varicose veins (10) }\end{array}$ & $\begin{array}{l}\text { The infusion or decoction of the } \\
\text { flowers and leaves is used for the } \\
\text { washing on affected area. They are } \\
\text { also used as foments. The leaves } \\
\text { infusion is taken orally. }\end{array}$ & $\begin{array}{l}\text { Mexican medicine, to purify the blood } \\
\text { as well as in erysipelas, syphilis, scabies, } \\
\text { tumors, pimples and skin inflammations. } \\
\text { In Guatemala, for treating eruptions and } \\
\text { erysipelas. }\end{array}$ & $\begin{array}{l}\text { Cáceres et al., 1987; } \\
\text { Andrade-Cetto, 2009; } \\
\text { BDMTM, 2009; } \\
\text { Ávila-Uribe et al., } \\
2016 .\end{array}$ \\
\hline \multicolumn{7}{|l|}{ Adoxaceae } \\
\hline Sambucus nigra L. (256844) & sauco, cundemba & yes & $\begin{array}{l}0.05 / \text { cuts }(50), \text { burns }(25), \\
\text { pruritus }(25), \text { rash }(25)\end{array}$ & $\begin{array}{l}\text { The leaves are rubbed on the affected } \\
\text { area. The decoction of leaves and bark } \\
\text { is used to wash the lesions. With the } \\
\text { aqueous bark extract ointments are } \\
\text { made. }\end{array}$ & $\begin{array}{l}\text { Spain, Italy and Malta for treating scalps, } \\
\text { erysipelas and other skin disorders. }\end{array}$ & $\begin{array}{l}\text { Guarrera et al., 2005; } \\
\text { Benítez et al., 2010; } \\
\text { Caruana and Attard, } \\
2016 .\end{array}$ \\
\hline
\end{tabular}

\section{Amaranthaceae}

Alternanthera caracasana Kunth (256863)

tianguis

Chenopodium ambrosioides L. (256898)

epazote

hierba de arlomo

yes

Iresine interrupta Benth. (256862)

made.

0.09/rash (62.5), skin bumps (50), varicella (25) for washing the affected skin area.

$0.02 /$ cuts $(100)$

The decoction from leaves is used for washing the affected skin area.

yes

0.08/insect bites (100), The aerial part is crushed, and the warts (28.6) psoriasis (14.3) paste or tincture is applied on skin lesions. The infusion of leaves is used for washing the affected area.
Canales-Martínez et al., 2005.

Cáceres et al., 1987;

Cuba, for cutaneous leishmaniasis. In Guatemala, for burns, skin irritation and wounds.

Mexican traditional medicine, for insect bites.

Monzote et al., 2009.

BIOAGRICOOP, 1998; NavarreteHeredia and Gómez Flores, 2005. 
Appendix: Continuation.

\begin{tabular}{|c|c|c|c|c|c|c|}
\hline $\begin{array}{l}\text { Scientific name (voucher specimen number } \\
\text { in the herbarium IEB) }\end{array}$ & Vernacular name & $\begin{array}{l}\text { Native plant } \\
\text { of Mexico }\end{array}$ & $\begin{array}{l}\text { Use Value/Dermatological } \\
\text { conditions (fidelity level) }\end{array}$ & $\begin{array}{l}\text { Mode of preparation by inhabitants } \\
\text { from the Purépecha Plateau }\end{array}$ & $\begin{array}{l}\text { Ethnomedicinal studies worldwide } \\
\text { mentioning the use of the species for } \\
\text { dermatological conditions }\end{array}$ & References \\
\hline \multicolumn{7}{|l|}{ Amaryllidaceae } \\
\hline Allium cepa L. (256837) & cebolla & no & $\begin{array}{l}0.09 \text { /burns }(50), \text { hematomas } \\
(37.5) \text {, hair fall }(12.5)\end{array}$ & $\begin{array}{l}\text { The bulb is crushed, and the paste is } \\
\text { applied on affected skin area. }\end{array}$ & $\begin{array}{l}\text { Reported in Mexico for the treatment } \\
\text { of cuts, skin bumps and hair fall. } \\
\text { Tharu community in India used it for } \\
\text { the treatment of ringworm and skin } \\
\text { allergy. In the Sarrabus region, Italy, } \\
\text { used as antiherpetic. In North Pakistan } \\
\text { for treating soothe irritation caused by } \\
\text { scorpion and hornet stings. In Edo State, } \\
\text { Nigeria for rashes and stings. In Central } \\
\text { Chaco, Argentina, for bites and warts. In } \\
\text { Terengganu, Malaysia, for treating cuts, } \\
\text { sores, pimples and abscess. In Morocco for } \\
\text { leprosy and skin cancer. }\end{array}$ & $\begin{array}{l}\text { Palmese et al., } \\
\text { 2001; Egharevba } \\
\text { and Ikhatua, 2008; } \\
\text { BDMTM, 2009; } \\
\text { Martínez and Barboza, } \\
\text { 2010; El Mansouri et } \\
\text { al., 2011; Ong et al., } \\
\text { 2011; Akhtar et al., } \\
\text { 2013; Sharma et al., } \\
\text { 2014. }\end{array}$ \\
\hline Allium sativum $\mathrm{L}$. & ajo & no & $\begin{array}{l}0.13 \text { /fungal infections } \\
(54.5), \text { calluses }(18.2), \\
\text { psoriasis (18.2), skin } \\
\text { bumps (18.2), warts (18.2), } \\
\text { superficial infections (18.2), } \\
\text { skin inflammation (9.1), } \\
\text { varicose veins (9.1) }\end{array}$ & $\begin{array}{l}\text { The bulb is crushed, and the paste } \\
\text { is applied on affected skin area. Its } \\
\text { alcoholic extract is applied externally } \\
\text { on lesions. With the oily bulb extract } \\
\text { ointments are prepared. }\end{array}$ & $\begin{array}{l}\text { Sarrabus region, Italy, used against insect } \\
\text { bites to lessen the pruritus. In North } \\
\text { Pakistan for treating soothe irritation } \\
\text { caused by scorpion and hornet stings. } \\
\text { In Central Chaco, Argentina, for bites } \\
\text { and warts. In Terengganu, Malaysia for } \\
\text { treating stings, bites, and cuts. In Mexico, } \\
\text { for warts, ringworm, varicose veins and } \\
\text { insect stings. }\end{array}$ & $\begin{array}{l}\text { Palmese et al., 2001; } \\
\text { Andrade-Cetto, } \\
\text { 2009; BDMTM, } \\
\text { 2009; Martínez and } \\
\text { Barboza, 2010; Ong } \\
\text { et al., 2011; Akhtar et } \\
\text { al., 2013. }\end{array}$ \\
\hline \multicolumn{7}{|l|}{ Anacardiaceae } \\
\hline $\begin{array}{l}\text { Amphipterygium adstringens Schiede ex } \\
\text { Standl. (256881) }\end{array}$ & cuachalalate & yes & $\begin{array}{l}0.15 / \text { cuts }(92.3) \text {, skin } \\
\text { inflammation ( } 38.5) \text {, } \\
\text { burns (15.4), rash (15.4), } \\
\text { infections with abscesses } \\
\text { (7.7), insect bites ( } 7.7) \text {, skin } \\
\text { bumps (7.7) }\end{array}$ & $\begin{array}{l}\text { The decoction of its bark is taken } \\
\text { orally and is also used for washing } \\
\text { lesions. The aqueous bark extract is } \\
\text { used for ointment preparation. }\end{array}$ & $\begin{array}{l}\text { Mexican traditional medicine for wounds, } \\
\text { pimples, scabs, bumps, abscesses, skin } \\
\text { inflammation, hair loss and blemishes. }\end{array}$ & $\begin{array}{l}\text { Cuevas Figueroa, } \\
\text { 2005; BDMTM, } 2009 .\end{array}$ \\
\hline Schinus molle L. (256869) & pirul & no & $\begin{array}{l}0.02 / \text { cuts }(50), \text { psoriasis } \\
(50)\end{array}$ & $\begin{array}{l}\text { The alcoholic extract from leaves is } \\
\text { used in fomentation form. }\end{array}$ & $\begin{array}{l}\text { Mexican traditional medicine, as } \\
\text { cicatrizing agent. In Brazil, as cicatrizing } \\
\text { agent. }\end{array}$ & $\begin{array}{l}\text { Oliveira et al., 2007; } \\
\text { BDMTM, } 2009 .\end{array}$ \\
\hline
\end{tabular}


Appendix: Continuation.

\begin{tabular}{|c|c|c|c|c|c|c|}
\hline $\begin{array}{l}\text { Scientific name (voucher specimen number } \\
\text { in the herbarium IEB) }\end{array}$ & Vernacular name & $\begin{array}{l}\text { Native plant } \\
\text { of Mexico }\end{array}$ & $\begin{array}{l}\text { Use Value/Dermatological } \\
\text { conditions (fidelity level) }\end{array}$ & $\begin{array}{l}\text { Mode of preparation by inhabitants } \\
\text { from the Purépecha Plateau }\end{array}$ & $\begin{array}{l}\text { Ethnomedicinal studies worldwide } \\
\text { mentioning the use of the species for } \\
\text { dermatological conditions }\end{array}$ & References \\
\hline \multicolumn{7}{|l|}{ Annonaceae } \\
\hline Annona cherimola Mill. (256909) & chirimoyo & no & $0.02 /$ skin inflammation $(50)$ & The infusion of leaves is taken orally. & $\begin{array}{l}\text { Mexico for treatment of bruising, dandruff, } \\
\text { skin infections and pimples. }\end{array}$ & BDMTM, 2009. \\
\hline \multicolumn{7}{|l|}{ Apiaceae } \\
\hline $\begin{array}{l}\text { Eryngium beecheyanum Hook. f. \& Arn. } \\
\text { (256900) }\end{array}$ & hierba del sapo & yes & $\begin{array}{l}0.02 / \text { skin inflammation } \\
(100)\end{array}$ & $\begin{array}{l}\text { The infusion of the aerial part is } \\
\text { taken orally. Additionally, it is used in } \\
\text { fomentation form on skin. }\end{array}$ & Not reported. & \\
\hline \multicolumn{7}{|l|}{ Apocynaceae } \\
\hline Asclepias curassavica L. (256905) & dominguilla & no & $\begin{array}{l}0.08 / \text { skim bumps }(57.1), \\
\text { warts }(42.9), \text { calluses }(28.6)\end{array}$ & $\begin{array}{l}\text { The latex of leaves and stems is } \\
\text { applied on the skin injury, avoiding } \\
\text { contact with healthy skin. }\end{array}$ & $\begin{array}{l}\text { Mexico, for treating skin bumps, scabies, } \\
\text { erysipelas, edemas, stings of insects and } \\
\text { wounds. }\end{array}$ & BDMTM, 2009. \\
\hline \multicolumn{7}{|l|}{ Asphodelaceae } \\
\hline Aloe vera (L.) Burm. f. (256851) & sábila & no & $\begin{array}{l}0.37 / \text { cuts (62.5), skin } \\
\text { inflammation (28.1), hair } \\
\text { fall (21.9), hematomas } \\
\text { (21.9), burns (18.8), } \\
\text { superficial infections (9.4), } \\
\text { infections with abscesses } \\
\text { (6.3), insect bites (6.3), } \\
\text { skin bumps (6.3), fungal } \\
\text { infections (3.1), psoriasis } \\
\text { (3.1), skin care (3.1) }\end{array}$ & $\begin{array}{l}\text { The pulp of the fresh or roasted leaves } \\
\text { is applied on the affected area. The } \\
\text { pulp is also used as shampoo. }\end{array}$ & $\begin{array}{l}\text { broadly used for the treatment of } \\
\text { dermatological affections. Used in } \\
\text { Mexico, for skin swelling and erysipelas } \\
\text { as cicatrizing agent. Additionally, it is } \\
\text { used for sunburns, bumps and melasma. } \\
\text { In Kelantan, Malaysia, it is used to } \\
\text { prevent pimples and to smooth the skin. } \\
\text { In district of Tamil Nadu, India, for hair } \\
\text { growth. Israelis used it for wound healing. } \\
\text { In Wayanad district, India for dandruff } \\
\text { treatment. }\end{array}$ & $\begin{array}{l}\text { Ong and Nordiana, } \\
\text { 1999; Lev, 2006; } \\
\text { Silja et al., 2008; } \\
\text { Andrade-Cetto, 2009; } \\
\text { BDMTM, 2009; } \\
\text { Benítez et al., 2010. }\end{array}$ \\
\hline \multicolumn{7}{|l|}{ Asteraceae } \\
\hline Artemisia ludoviciana Nutt. (256888) & $\begin{array}{l}\text { picanardo, } \\
\text { prodigiosa }\end{array}$ & yes & $\begin{array}{l}0.07 / \text { skin inflammation } \\
(100)\end{array}$ & $\begin{array}{l}\text { The aerial part is used as tincture or } \\
\text { infusion, using the oral dosage form. }\end{array}$ & $\begin{array}{l}\text { Mexican traditional medicine for treating } \\
\text { skin bumps and wounds. }\end{array}$ & BDMTM, 2009. \\
\hline $\begin{array}{l}\text { Artemisia mexicana Willd. ex Spreng. } \\
\text { (256907) }\end{array}$ & estafiate & yes & $\begin{array}{l}0.02 / \text { skin inflammation } \\
(100)\end{array}$ & $\begin{array}{l}\text { The infusion of the aerial part is taken } \\
\text { orally. The alcoholic extract of the } \\
\text { aerial part is used in fomentation form } \\
\text { on affected area. }\end{array}$ & $\begin{array}{l}\text { Mexican traditional medicine, to relieve } \\
\text { swelling of the feet. }\end{array}$ & Nicholson, 1991. \\
\hline Bidens pilosa L. (256838) & aceitilla & yes & $\begin{array}{l}0.05 / \text { cuts }(75), \text { skin bumps } \\
(50) \text {, hair fall ( } 25)\end{array}$ & $\begin{array}{l}\text { The infusion and decoction of the } \\
\text { aerial parts are used for washing the } \\
\text { affected skin area. }\end{array}$ & $\begin{array}{l}\text { Mexican traditional medicine, for treating } \\
\text { wounds, hair loss, skin irritation, skin } \\
\text { inflammation, and burns. In Trinidad and } \\
\text { Tobago for baby bath and cuts. }\end{array}$ & $\begin{array}{l}\text { Andrade-Cetto, 2009; } \\
\text { BDMTM, 2009; Lans, } \\
2007 .\end{array}$ \\
\hline
\end{tabular}


Appendix: Continuation.

\begin{tabular}{|c|c|c|c|c|c|c|}
\hline $\begin{array}{l}\text { Scientific name (voucher specimen number } \\
\text { in the herbarium IEB) }\end{array}$ & Vernacular name & $\begin{array}{l}\text { Native plant } \\
\text { of Mexico }\end{array}$ & $\begin{array}{l}\text { Use Value/Dermatological } \\
\text { conditions (fidelity level) }\end{array}$ & $\begin{array}{l}\text { Mode of preparation by inhabitants } \\
\text { from the Purépecha Plateau }\end{array}$ & $\begin{array}{l}\text { Ethnomedicinal studies worldwide } \\
\text { mentioning the use of the species for } \\
\text { dermatological conditions }\end{array}$ & References \\
\hline Calendula officinalis L. (256876) & $\begin{array}{l}\text { caléndula, } \\
\text { virreina }\end{array}$ & no & $\begin{array}{l}0.17 / \text { cuts (53.3), pruritus } \\
(26.7), \text { skin inflammation } \\
\text { (20), psoriasis (20), burns } \\
\text { (13.3), insect bites (13.3), } \\
\text { rash (13.3), superficial } \\
\text { infections (13.3), blemishes } \\
\text { (6.7), skin bumps (6.7) }\end{array}$ & $\begin{array}{l}\text { The infusion of leaves and flowers is } \\
\text { taken orally. Additionally, it is used } \\
\text { in fomentation form and for washing } \\
\text { the skin lesions. The alcoholic extract } \\
\text { from leaves and flowers is applied in } \\
\text { the affected skin area, being also used } \\
\text { in ointment preparation. }\end{array}$ & $\begin{array}{l}\text { Widely used for the treatment of skin } \\
\text { diseases. In Eastern Sikkim Himalayan } \\
\text { Region, it is used in healing wounds, } \\
\text { ulcers and burns. In Turkey, this plant is } \\
\text { reported in baths for dry skin. In Mexican } \\
\text { traditional medicine, for treating wounds } \\
\text { as disinfectant and antinflammatory agent. }\end{array}$ & $\begin{array}{l}\text { BDMTM, 2009; Das } \\
\text { et al., 2012; Ugulu, } \\
2012 .\end{array}$ \\
\hline Erigeron delphinifolius Willd. (256846) & árnica blanca & yes & $\begin{array}{l}0.08 / \text { skin inflammation } \\
(85.7), \text { hematomas }(14.3)\end{array}$ & $\begin{array}{l}\text { The infusion from its flowers and } \\
\text { leaves is taken orally. Additionally, it } \\
\text { is applied in fomentation form on the } \\
\text { affected skin area. }\end{array}$ & Mexico, for treating hematomas. & $\begin{array}{l}\text { Bello-González et al., } \\
2015 .\end{array}$ \\
\hline Heterotheca inuloides Cass. (256858) & árnica & yes & $\begin{array}{l}0.53 / \text { skin inflammation } \\
(56.5) \text {, hematomas ( } 45.7) \text {, } \\
\text { cuts (28.3), infections with } \\
\text { abscesses (4.3), skin bumps } \\
\text { (4.3), skin care (4.3), } \\
\text { superficial infections (4.3), } \\
\text { insect bites ( } 2.2) \text {, rash (2.2), } \\
\text { varicella (2.2), varicose } \\
\text { veins (2.2) }\end{array}$ & $\begin{array}{l}\text { The infusion from its leaves and } \\
\text { flowers is taken orally being also } \\
\text { used in fomentation form as well as } \\
\text { for washing the affected skin area. } \\
\text { The alcoholic extract is used on the } \\
\text { skin, being a part of preparation of } \\
\text { ointments. The infusions of the plant } \\
\text { are used in a steam bath for skin health } \\
\text { "temazcal". }\end{array}$ & $\begin{array}{l}\text { Mexico, for the treatment of wounds, } \\
\text { internal and external blows, bruises, } \\
\text { cutaneous lesions, infected or not, such } \\
\text { as pimples, sores, bruises, hives, baby } \\
\text { scrapes, erysipelas and skin inflammation. }\end{array}$ & $\begin{array}{l}\text { Navarro Pérez and } \\
\text { Avendaño Reyes, } \\
\text { 2002; Andrade-Cetto, } \\
\text { 2009; BDMTM, 2009; } \\
\text { Monroy-Ortiz et al., } \\
\text { 2013; Bello-González } \\
\text { et al., 2015. }\end{array}$ \\
\hline Lactuca sativa $\mathrm{L}$. & lechuga & no & $0.03 /$ rash $(100)$ & $\begin{array}{l}\text { The infusion of its leaves is used as } \\
\text { a bath. }\end{array}$ & $\begin{array}{l}\text { Jordanian traditional medicine, it is used } \\
\text { as emollient and hair tonic. }\end{array}$ & Al-Khalil, 1995. \\
\hline Matricaria recutita L. (256875) & manzanilla & no & $\begin{array}{l}0.12 / \text { cuts }(30) \text {, rash }(30) \text {, } \\
\text { blemishes (10), hematomas } \\
(10) \text {, skin inflammation } \\
\text { (20), pruritus (20), skin } \\
\text { bumps (10), superficial } \\
\text { infections (10) }\end{array}$ & $\begin{array}{l}\text { The infusion of the aerial part of this } \\
\text { plant, mainly its flowers, is used in } \\
\text { fomentation form and for washing the } \\
\text { skin area. The oily flower extract is } \\
\text { applied at the injury site. }\end{array}$ & $\begin{array}{l}\text { Its cosmetic value has been established } \\
\text { through years of traditional use worldwide. } \\
\text { In Mexico, it is used for scorpion stings, } \\
\text { wound washing, removal of pimples and } \\
\text { to lighten the hair. Among Albanians, } \\
\text { Macedonians and Gorani in the Sharr } \\
\text { Mountains, it is used for wound healing. In } \\
\text { Kopaonik Mountain (Central Serbia) used } \\
\text { externally for skin and mucous complaints } \\
\text { (burns, wounds and ulcers). In the Potosi } \\
\text { Department, Bolivia, it is used for wounds } \\
\text { and acne. }\end{array}$ & $\begin{array}{l}\text { Fernandez et al., } \\
\text { 2003; Jarić et al., } \\
\text { 2007; BDMTM, 2009; } \\
\text { Rexhepi et al., } 2013 .\end{array}$ \\
\hline
\end{tabular}


Appendix: Continuation.

\begin{tabular}{|c|c|c|c|c|c|c|}
\hline $\begin{array}{l}\text { Scientific name (voucher specimen number } \\
\text { in the herbarium IEB) }\end{array}$ & Vernacular name & $\begin{array}{l}\text { Native plant } \\
\text { of Mexico }\end{array}$ & $\begin{array}{l}\text { Use Value/Dermatological } \\
\text { conditions (fidelity level) }\end{array}$ & $\begin{array}{l}\text { Mode of preparation by inhabitants } \\
\text { from the Purépecha Plateau }\end{array}$ & $\begin{array}{l}\text { Ethnomedicinal studies worldwide } \\
\text { mentioning the use of the species for } \\
\text { dermatological conditions }\end{array}$ & References \\
\hline Montanoa tomentosa Cerv. (256859) & gobernadora & yes & $\begin{array}{l}0.03 / \text { rash }(100), \text { insect bites } \\
(66.7)\end{array}$ & $\begin{array}{l}\text { The infusion of the aerial part is taken } \\
\text { orally, being used to wash the affected } \\
\text { area. }\end{array}$ & $\begin{array}{l}\text { Mexico, to treat a cultural disease } \\
\text { called "burned" in which a woman may } \\
\text { have blemishes, hematomas and skin } \\
\text { inflammation after childbirth. }\end{array}$ & $\begin{array}{l}\text { BDMTM, 2009; } \\
\text { Gómez Aiza, 2013; } \\
\text { Ávila-Uribe et al., } \\
2016 .\end{array}$ \\
\hline Piqueria trinervia Cav. (256861) & culikumanchicua & yes & $0.01 /$ cuts $(100)$ & $\begin{array}{l}\text { The infusion of its aerial parts is } \\
\text { taken orally. Moreover, it is used for } \\
\text { washing the affected skin area. }\end{array}$ & $\begin{array}{l}\text { Mexico, it is used to treat skin bumps and } \\
\text { hives, for washing wounds and controlling } \\
\text { the measles and rash. }\end{array}$ & BDMTM, 2009. \\
\hline Senecio salignus DC. (256877) & jara amarilla & no & $\begin{array}{l}0.06 / \text { hematomas (40), skin } \\
\text { bumps (40), cuts (20), skin } \\
\text { inflammation (20), }\end{array}$ & $\begin{array}{l}\text { The decoction of flowers and leaves } \\
\text { is used to wash the skin and in } \\
\text { fomentation form on the affected area. } \\
\text { The leaves are crushed with salt and } \\
\text { the paste is applied on the injury site. }\end{array}$ & $\begin{array}{l}\text { Abbotabad City, Pakistan used against } \\
\text { snake bite and as antiseptic over wounds. } \\
\text { It is also used for treating swelling of } \\
\text { joints. }\end{array}$ & $\begin{array}{l}\text { Sabeen and Ahmad, } \\
2009 .\end{array}$ \\
\hline Sonchus oleraceus L. (256879) & achicoria & no & $\begin{array}{l}0.03 / \text { cuts }(100), \text { burns } \\
(33.3)\end{array}$ & $\begin{array}{l}\text { The decoction of the aerial part is used } \\
\text { in fomentation form and for washing } \\
\text { the affected area. The aerial part is } \\
\text { crushed, and the paste is applied at the } \\
\text { site of injury. }\end{array}$ & $\begin{array}{l}\text { Mexico, it is used for rash and blemishes } \\
\text { treatment. Malayali tribes in Dharmapuri, } \\
\text { India use it externally on wounds. In Italy } \\
\text { and Spain, it is used for treating warts. }\end{array}$ & $\begin{array}{l}\text { Guarrera et al., 2005; } \\
\text { Ramya et al., 2008; } \\
\text { BDMTM, 2009; } \\
\text { Benítez et al., 2010; } \\
\text { Bello-González et al., } \\
2015 .\end{array}$ \\
\hline Stevia serrata Cav. (256860) & hierba de burra & yes & $\begin{array}{l}\text { 0.03/rash (100), skin bumps } \\
(33.3)\end{array}$ & $\begin{array}{l}\text { The infusion of the flowers is taken } \\
\text { orally and is used to wash the sites of } \\
\text { injury. }\end{array}$ & Mexico used in cuts of feet. & Kinghorn, 2001. \\
\hline Tagetes erecta L. (256847) & $\begin{array}{l}\text { cempasúchil, } \\
\text { guarecita }\end{array}$ & yes & $0.03 /$ cuts $(66.7)$, rash $(33.3)$ & $\begin{array}{l}\text { The infusion of flowers and leaves is } \\
\text { used for washing the skin. The flowers } \\
\text { are rubbed directly on the affected } \\
\text { area. }\end{array}$ & $\begin{array}{l}\text { Mexican traditional medicine, for treating } \\
\text { erysipelas, wounds, rash, sores, warts } \\
\text { and pimples. In Bangladesh, for treating } \\
\text { eczema, abscess, acne, boils, scabies, itch, } \\
\text { infections, dermatitis, rash, sores, scar and } \\
\text { warts. In Iran, for treating wounds. }\end{array}$ & $\begin{array}{l}\text { Andrade-Cetto, 2009; } \\
\text { BDMTM, 2009; } \\
\text { Mollik et al., 2010; } \\
\text { Amiri and Joharchi, } \\
2013 \text {. }\end{array}$ \\
\hline Tagetes filifolia Lag. (256840) & anís de grano & yes & $\begin{array}{l}0.07 / \text { skin bumps }(83.3) \text {, } \\
\text { cuts }(16.7), \text { rash }(16.7)\end{array}$ & $\begin{array}{l}\text { The infusion of the grains is taken } \\
\text { orally and is applied in fomentation } \\
\text { form. The aerial parts are crushed, and } \\
\text { the paste is applied at the injury site. }\end{array}$ & $\begin{array}{l}\text { Mexico, it is used in baths for skin care. In } \\
\text { Argentinian traditional medicine, for itch, } \\
\text { and healing infected wounds. }\end{array}$ & $\begin{array}{l}\text { BDMTM, 2009; } \\
\text { Zacchino et al., } 2012 .\end{array}$ \\
\hline
\end{tabular}


Appendix: Continuation.

\begin{tabular}{|c|c|c|c|c|c|c|}
\hline $\begin{array}{l}\text { Scientific name (voucher specimen number } \\
\text { in the herbarium IEB) }\end{array}$ & Vernacular name & $\begin{array}{l}\text { Native plant } \\
\text { of Mexico }\end{array}$ & $\begin{array}{l}\text { Use Value/Dermatological } \\
\text { conditions (fidelity level) }\end{array}$ & $\begin{array}{l}\text { Mode of preparation by inhabitants } \\
\text { from the Purépecha Plateau }\end{array}$ & $\begin{array}{l}\text { Ethnomedicinal studies worldwide } \\
\text { mentioning the use of the species for } \\
\text { dermatological conditions }\end{array}$ & References \\
\hline Tagetes lucida Cav. (256843) & santa María & yes & $\begin{array}{l}0.05 / \text { cuts }(100), \text { skin care } \\
(25), \text { superficial infections } \\
(25)\end{array}$ & $\begin{array}{l}\text { The infusion of the aerial part is used } \\
\text { for washing the affected area. }\end{array}$ & $\begin{array}{l}\text { Mexican traditional medicine, for varicose } \\
\text { veins and skin inflammation. }\end{array}$ & BDMTM, 2009. \\
\hline Tagetes remotiflora Kunze (256839) & cinco llagas & no & $\begin{array}{l}0.05 / \text { cuts }(100) \text {, superficial } \\
\text { infections }(50)\end{array}$ & $\begin{array}{l}\text { The infusion from the aerial part or } \\
\text { roots is used for washing the affected } \\
\text { area. The flowers and leaves are also } \\
\text { used as infusion. }\end{array}$ & Not reported. & \\
\hline $\begin{array}{l}\text { Tanacetum parthenium (L.) Sch. Bip. } \\
\text { (256896) }\end{array}$ & bola de hilo & no & $0.01 /$ insect bites $(100)$ & $\begin{array}{l}\text { The infusion from the aerial part is } \\
\text { taken orally and used for washing skin } \\
\text { lesions. }\end{array}$ & $\begin{array}{l}\text { Mexico, for skin inflammation. In Iran for } \\
\text { hair care. }\end{array}$ & $\begin{array}{l}\text { Andrade-Cetto, 2009; } \\
\text { Amiri and Joharchi, } \\
2013 .\end{array}$ \\
\hline Taraxacum officinale F.H. Wigg. (256852) & diente de león & no & $\begin{array}{l}\text { 0.03/infections with } \\
\text { abscesses (66.7), rash } \\
(33.3)\end{array}$ & $\begin{array}{l}\text { The infusion from the aerial part is } \\
\text { used for washing the affected skin, } \\
\text { being also taken orally. }\end{array}$ & $\begin{array}{l}\text { Mexican traditional medicine, for treating } \\
\text { skin bumps, scabies, abscesses, acne and } \\
\text { skin infections. In Central Italy for treating } \\
\text { warts. } \\
\text { In Himachal Pradesh, to cure boils. }\end{array}$ & $\begin{array}{l}\text { Guarrera, 2005; } \\
\text { Hurtado-Rico et al., } \\
\text { 2006; Lal and Singh, } \\
\text { 2008; BDMTM, 2009. }\end{array}$ \\
\hline $\begin{array}{l}\text { Tithonia diversifolia (Hemsl.) A. Gray } \\
\text { (256922) }\end{array}$ & capitaneja & yes & $\begin{array}{l}0.06 / \text { cuts }(40), \text { infections } \\
\text { with abscesses }(40), \\
\text { superficial infections }(40)\end{array}$ & $\begin{array}{l}\text { The infusion of flowers and leaves, for } \\
\text { washing the skin affected area. It is } \\
\text { also used for ointment preparation. }\end{array}$ & $\begin{array}{l}\text { Mexico, it is used to cure bumps, sores } \\
\text { and wounds. In addition, it is used for } \\
\text { scabies, pimples, blackheads and for } \\
\text { removing itching. Among Kalanguya tribe } \\
\text { in Philipines for treating cuts and wounds. } \\
\text { In Western Uganda, as antifungal and } \\
\text { antibacterial agent. }\end{array}$ & $\begin{array}{l}\text { Kamatenesi-Mugisha } \\
\text { et al., 2008; BDMTM, } \\
\text { 2009; Balangcod and } \\
\text { Balangcod, 2011. }\end{array}$ \\
\hline \multicolumn{7}{|l|}{ Boraginaceae } \\
\hline Borago officinalis L. (256850) & borraja & no & $\begin{array}{l}0.07 / \text { skin inflammation } \\
(50) \text {, pruritus (33.3), rash } \\
\text { (33.3), psoriasis (16.7), skin } \\
\text { bumps (16.7) }\end{array}$ & $\begin{array}{l}\text { The infusion of the aerial part is } \\
\text { taken orally and used for washing the } \\
\text { affected area. Additionally, it is used in } \\
\text { fomentation form. }\end{array}$ & $\begin{array}{l}\text { Malta, for skin disorders and minor } \\
\text { wounds. }\end{array}$ & $\begin{array}{l}\text { Caruana and Attard, } \\
2016 .\end{array}$ \\
\hline Tournefortia mutabilis Vent. (256856) & hoja de lija & yes & $\begin{array}{l}0.03 / \text { cuts }(66.7) \text {, superficial } \\
\text { infections }(66.7)\end{array}$ & $\begin{array}{l}\text { The decoction of the aerial part is used } \\
\text { for washing the affected area. }\end{array}$ & Not reported. & \\
\hline \multicolumn{7}{|l|}{ Brassicaceae } \\
\hline Lepidium virginicum L. (256908) & panalillo & yes & $\begin{array}{l}0.03 \text { /infections with } \\
\text { abscesses (100) }\end{array}$ & $\begin{array}{l}\text { The infusion of flowers and leaves is } \\
\text { used for washing skin. }\end{array}$ & $\begin{array}{l}\text { Mexican traditional medicine, it is used for } \\
\text { rash, burns and scrapes. }\end{array}$ & BDMTM, 2009. \\
\hline
\end{tabular}


Appendix: Continuation.

\begin{tabular}{|c|c|c|c|c|c|c|}
\hline $\begin{array}{l}\text { Scientific name (voucher specimen number } \\
\text { in the herbarium IEB) }\end{array}$ & Vernacular name & $\begin{array}{c}\text { Native plant } \\
\text { of Mexico }\end{array}$ & $\begin{array}{l}\text { Use Value/Dermatological } \\
\text { conditions (fidelity level) }\end{array}$ & $\begin{array}{l}\text { Mode of preparation by inhabitants } \\
\text { from the Purépecha Plateau }\end{array}$ & $\begin{array}{l}\text { Ethnomedicinal studies worldwide } \\
\text { mentioning the use of the species for } \\
\text { dermatological conditions }\end{array}$ & References \\
\hline \multicolumn{7}{|l|}{ Burseraceae } \\
\hline Bursera bipinnata (DC.) Engl. (256867) & copal & yes & $\begin{array}{l}0.03 / \text { superficial infections } \\
(100), \text { cuts }(66.7)\end{array}$ & $\begin{array}{l}\text { The resin is applied directly on the } \\
\text { injured skin. }\end{array}$ & $\begin{array}{l}\text { Mexican traditional medicine on wounds } \\
\text { and skin infections. }\end{array}$ & BDMTM, 2009. \\
\hline \multicolumn{7}{|l|}{ Commelinaceae } \\
\hline Commelina diffusa Burm. f. (256889) & hierba de pollo & yes & $\begin{array}{l}0.03 / \text { cuts }(100), \text { insect bites } \\
(33.3)\end{array}$ & $\begin{array}{l}\text { The decoction of the aerial part is } \\
\text { taken orally and used for washing skin. } \\
\text { The leaves are crushed, and the paste } \\
\text { is applied directly on the lesions. }\end{array}$ & $\begin{array}{l}\text { South Orissa, India, to heal burn injuries, } \\
\text { itches, and boils. In Nagaon District, to } \\
\text { stop bleeding of wounds and cuts. }\end{array}$ & $\begin{array}{l}\text { Sarma and Saikia, } \\
\text { 2010; Panda and } \\
\text { Misra, } 2011 .\end{array}$ \\
\hline \multicolumn{7}{|l|}{ Convolvulaceae } \\
\hline $\begin{array}{l}\text { Ipomoea murucoides Roem. \& Schult. } \\
\text { (256878) }\end{array}$ & cazahuate & yes & $\begin{array}{l}0.02 / \text { infections with } \\
\text { abscesses (100), burns (50) }\end{array}$ & $\begin{array}{l}\text { The infusion of flowers and stems is } \\
\text { used for washing the affected area. }\end{array}$ & $\begin{array}{l}\text { Mexico, it is used for the treatment of hair } \\
\text { loss and rash as well as to remove nails } \\
\text { and for managing scorpion stings. }\end{array}$ & $\begin{array}{l}\text { Hurtado-Rico et al., } \\
\text { 2006; BDMTM, } 2009 .\end{array}$ \\
\hline \multicolumn{7}{|l|}{ Equisetaceae } \\
\hline $\begin{array}{l}\text { Equisetum hyemale var. affine (Engelm.) } \\
\text { A.A. Eaton (256870) }\end{array}$ & cola de caballo & yes & $\begin{array}{l}0.05 / \text { skin inflammation } \\
(50), \text { hair fall ( } 50) \text {, fungal } \\
\text { infections ( } 25)\end{array}$ & $\begin{array}{l}\text { The infusion of the aerial part is taken } \\
\text { orally and used for washing skin. A } \\
\text { shampoo is also prepared with this } \\
\text { plant. }\end{array}$ & Not reported. & \\
\hline
\end{tabular}

\section{Euphorbiaceae}

Euphorbia nutans Lag. (256885)

hierba de la $\quad$ yes $\quad 0.05 /$ rash (100)

The infusion of the whole plant is used Croatia, for treating warts. in fomentation form, baths and for

Pieroni et al., 2003.

golondrina

washing the affected skin area.

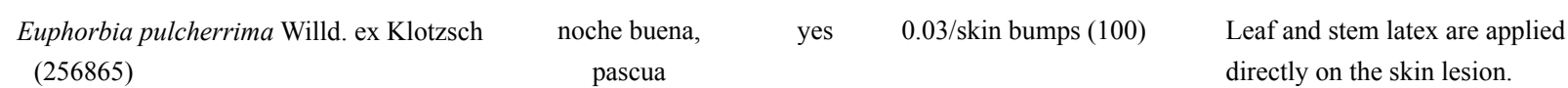

Mexico, for treating warts, erysipelas, sores, skin infections and wounds. For the management of inflammations and blows. In Lawachara National Park, Bangladesh, for cut injury. In Central Nepal to relieve boils, it is also useful for treating skin diseases.

\section{Fabaceae}

Caesalpinia coriaria (Jacq.) Willd. (256903)

cascalote

no
The decoction of the fruits is used in fomentation form and for washing the affected skin area.
Mexican traditional medicine for scabies and blemishes. In Tamilnadu, South India for treatment of acne.
BDMTM, 2009; Malla and Chhetri, 2009; Uddin et al., 2012.

\section{BDMTM, 2009;} Vivekraj and Anandgideon, 2015. 
Appendix: Continuation.

\begin{tabular}{|c|c|c|c|c|c|c|}
\hline $\begin{array}{l}\text { Scientific name (voucher specimen number } \\
\text { in the herbarium IEB) }\end{array}$ & Vernacular name & $\begin{array}{l}\text { Native plant } \\
\text { of Mexico }\end{array}$ & $\begin{array}{l}\text { Use Value/Dermatological } \\
\text { conditions (fidelity level) }\end{array}$ & $\begin{array}{l}\text { Mode of preparation by inhabitants } \\
\text { from the Purépecha Plateau }\end{array}$ & $\begin{array}{l}\text { Ethnomedicinal studies worldwide } \\
\text { mentioning the use of the species for } \\
\text { dermatological conditions }\end{array}$ & References \\
\hline \multicolumn{7}{|l|}{ Fagaceae } \\
\hline Quercus rugosa Née (256835) & encino & yes & $\begin{array}{l}0.05 / \text { superficial infections } \\
\text { (75), cuts (50), burns (25), } \\
\text { infections with abscesses } \\
(25), \text { psoriasis }(25)\end{array}$ & $\begin{array}{l}\text { The decoction of its bark is used for } \\
\text { washing skin. }\end{array}$ & $\begin{array}{l}\text { Mexico, for treating sores, skin ulcers and } \\
\text { bumps. }\end{array}$ & $\begin{array}{l}\text { Luna-José et al., 2003; } \\
\text { BDMTM, } 2009 .\end{array}$ \\
\hline \multicolumn{7}{|l|}{ Geraniaceae } \\
\hline Geranium seemannii Peyr. (256887) & pata de león & yes & $0.02 /$ cuts $(100)$ & $\begin{array}{l}\text { The infusion of the aerial part is used } \\
\text { for washing skin. }\end{array}$ & $\begin{array}{l}\text { Mexican traditional medicine for urticaria, } \\
\text { scabies, wounds and skin inflammation, } \\
\text { sores, pimples, scabs, bruises. }\end{array}$ & $\begin{array}{l}\text { BDMTM, 2009; } \\
\text { Bello-González et al., } \\
\text { 2015; Ávila-Uribe et } \\
\text { al., } 2016 .\end{array}$ \\
\hline \multicolumn{7}{|l|}{ Lamiaceae } \\
\hline $\begin{array}{l}\text { Agastache mexicana (Kunth) Linf \& Epling } \\
\text { Det. B. Bedolla (256916) }\end{array}$ & toronjil & yes & $\begin{array}{l}0.05 / \text { skin inflammation } \\
(75), \text { psoriasis }(25), \text { rash } \\
(25)\end{array}$ & $\begin{array}{l}\text { The infusion of the aerial parts is } \\
\text { taken orally. Additionally, it is used in } \\
\text { fomentation form and for washing the } \\
\text { affected skin areas. }\end{array}$ & $\begin{array}{l}\text { Mexico, for burns and insect bites. It is } \\
\text { also used as antiseptic. }\end{array}$ & $\begin{array}{l}\text { Andrade-Cetto, 2009; } \\
\text { BDMTM, } 2009 .\end{array}$ \\
\hline $\begin{array}{l}\text { Clinopodium macrostemum (Moc. \& Sessé } \\
\text { ex Benth.) Kuntze (256910) }\end{array}$ & $\begin{array}{l}\text { nurite, te del } \\
\text { monte }\end{array}$ & yes & $\begin{array}{l}\text { 0.07/skin inflammation } \\
(83.3), \text { insect bites }(16.7)\end{array}$ & $\begin{array}{l}\text { The infusion of leaves is taken orally, } \\
\text { being also used in fomentation form } \\
\text { and baths. }\end{array}$ & Not reported. & \\
\hline Lavandula officinalis Chaix (256913) & lavanda & no & $\begin{array}{l}0.05 / \text { skin care }(75) \text {, hair fall } \\
(25), \text { pruritus }(25)\end{array}$ & $\begin{array}{l}\text { The infusion of the aerial parts is used } \\
\text { for washing the affected skin area. It is } \\
\text { also used for lotion preparation. }\end{array}$ & $\begin{array}{l}\text { Southern Italy, in the preparation of anti- } \\
\text { varicose mixtures. }\end{array}$ & De Feo et al., 1992. \\
\hline Leonotis nepetifolia (L.) R. Br (256919) & castilleja & no & $\begin{array}{l}0.02 / \text { cuts }(100), \text { superficial } \\
\text { infections }(50)\end{array}$ & $\begin{array}{l}\text { The infusion of the aerial part is used } \\
\text { for washing the affected skin area. }\end{array}$ & $\begin{array}{l}\text { Bidar district, India, it is used for treating } \\
\text { head sores. In Eastern Himalayan region } \\
\text { of India for treating burns. In Middle } \\
\text { (Grand) Caicos, Turks and Caicos Islands } \\
\text { (West Indies) for treating eczemas, wound } \\
\text { and skin disorders. }\end{array}$ & $\begin{array}{l}\text { Halberstein, } \\
\text { 1997; Kala, 2005; } \\
\text { Prashantkumar and } \\
\text { Vidyasagar, } 2008 .\end{array}$ \\
\hline $\begin{array}{l}\text { Lepechinia caulescens (Ortega) Epling } \\
\text { (256929) }\end{array}$ & salvia & yes & $\begin{array}{l}0.06 / \text { skin care }(60), \text { cuts } \\
(40), \text { superficial infections } \\
\text { (20) }\end{array}$ & $\begin{array}{l}\text { The infusion of the aerial part of this } \\
\text { plant is used to wash the sites of injury } \\
\text { and in a steam bath "temazcal". The } \\
\text { flower and leaf lotion is applied over } \\
\text { the affected area. }\end{array}$ & $\begin{array}{l}\text { Mexico, it is used to treat swelling and } \\
\text { blows. }\end{array}$ & $\begin{array}{l}\text { Navarro Pérez and } \\
\text { Avendaño Reyes, } \\
\text { 2002; Bello-González } \\
\text { et al., 2015. }\end{array}$ \\
\hline
\end{tabular}


Appendix: Continuation.

\begin{tabular}{|c|c|c|c|c|c|c|}
\hline $\begin{array}{l}\text { Scientific name (voucher specimen number } \\
\text { in the herbarium IEB) }\end{array}$ & Vernacular name & $\begin{array}{l}\text { Native plant } \\
\text { of Mexico }\end{array}$ & $\begin{array}{l}\text { Use Value/Dermatological } \\
\text { conditions (fidelity level) }\end{array}$ & $\begin{array}{l}\text { Mode of preparation by inhabitants } \\
\text { from the Purépecha Plateau }\end{array}$ & $\begin{array}{l}\text { Ethnomedicinal studies worldwide } \\
\text { mentioning the use of the species for } \\
\text { dermatological conditions }\end{array}$ & References \\
\hline Marrubium vulgare L. (256911) & manrubio & no & $\begin{array}{l}\text { 0.05/skin inflammation } \\
(100)\end{array}$ & $\begin{array}{l}\text { The infusion from the aerial part of } \\
\text { this plant is used in fomentation form. }\end{array}$ & $\begin{array}{l}\text { Mexico, it is used for blemishes, scabies, } \\
\text { pimples, wounds, fungus, measles, } \\
\text { dandruff and in cases of hair loss. In } \\
\text { Southern Italy, it is used as disinfectant for } \\
\text { small wounds. In North of Morocco, used } \\
\text { to treat abscesses, in Spain for erysipelas } \\
\text { and herpes. }\end{array}$ & $\begin{array}{l}\text { Navarro Pérez and } \\
\text { Avendaño Reyes, } \\
\text { 2002; Leporatti and } \\
\text { Guarrera, 2007; } \\
\text { BDMTM, 2009; } \\
\text { Benítez et al., 2010; } \\
\text { Khabbach et al., 2012; } \\
\text { Juárez-Vázquez et al., } \\
2013 \text {. }\end{array}$ \\
\hline Ocimum basilicum L. (256912) & albahacar & yes & $\begin{array}{l}0.02 / \text { blemishes }(50) \text {, rash } \\
(50)\end{array}$ & $\begin{array}{l}\text { The infusion of the aerial part is used } \\
\text { for washing skin. The leaves are } \\
\text { crushed, and the paste is applied to the } \\
\text { affected area. }\end{array}$ & $\begin{array}{l}\text { Mexico, for skin bumps and infections, } \\
\text { pimples and hair loss against ascaris and } \\
\text { sting of scorpion. Also, it is used for } \\
\text { varicose veins. In Kali Gandaki Watershed } \\
\text { Area, Nepal, for the treatment of fungal } \\
\text { skin infections. In West Cameroon, it is } \\
\text { used against mosquito bites. }\end{array}$ & $\begin{array}{l}\text { Navarro et al., 1996; } \\
\text { Joshi and Joshi, 2000; } \\
\text { Jiofack et al., 2008; } \\
\text { BDMTM, } 2009 .\end{array}$ \\
\hline Origanum majorana L. (256920) & mejorana & no & $0.03 /$ rash $(100)$ & $\begin{array}{l}\text { The infusion of the aerial part is used } \\
\text { as a bath. }\end{array}$ & $\begin{array}{l}\text { Samnium popular medicine, for treatment } \\
\text { of small abscesses and bruises. }\end{array}$ & Forgione et al., 2008. \\
\hline Rosmarinus officinalis L. (256918) & romero & no & $\begin{array}{l}0.16 / \text { hair fall (35.7), skin } \\
\text { care }(28.6) \text {, insect bites } \\
(14.3) \text {, hematomas }(7.1) \text {, } \\
\text { skin inflammation }(7.1) \text {, } \\
\text { psoriasis (7.1), rash (7.1), }\end{array}$ & $\begin{array}{l}\text { The infusion of the aerial part is used } \\
\text { for washing skin and in fomentation } \\
\text { form. It is also used as a hot bath in } \\
\text { the "temazcal". The alcoholic extract } \\
\text { of the aerial part is used in fomentation } \\
\text { form in the sites of skin injury. }\end{array}$ & $\begin{array}{l}\text { Mexico, it is used for skin problems, to } \\
\text { heal wounds, cancer sores and measles. } \\
\text { Additionally, it prevents hair loss, serves } \\
\text { to wash hair and against dandruff. It is } \\
\text { also used to treat blows. In North Sahara, } \\
\text { this plant is used for beauty care, hair } \\
\text { care, against snake bites and as cicatrizing } \\
\text { agent. In Spain as antinflammatory agent. } \\
\text { In Morocco, for treating wounds and skin } \\
\text { cancer. }\end{array}$ & $\begin{array}{l}\text { Andrade-Cetto, 2009; } \\
\text { BDMTM, 2009; } \\
\text { Benítez et al., 2010; } \\
\text { El Mansouri et al., } \\
\text { 2011; Maiza et al., } \\
\text { 2011; Khabbach et al., } \\
\text { 2012. }\end{array}$ \\
\hline Salvia amarissima Ortega (256915) & chan & yes & $\begin{array}{l}0.03 / \text { skin inflammation } \\
(66.7), \text { rash }(33.3)\end{array}$ & $\begin{array}{l}\text { The infusion from the aerial parts of } \\
\text { this plant is taken orally. It is also used } \\
\text { for washing the affected skin area. }\end{array}$ & Mexico, for hair care. & INEGI, 2014. \\
\hline Salvia leucantha Cav. (256914) & salvia & yes & $0.05 /$ skin care $(100)$ & $\begin{array}{l}\text { With its flowers an ointment is } \\
\text { prepared and applied directly on the } \\
\text { skin. }\end{array}$ & Not reported. & \\
\hline
\end{tabular}


Appendix: Continuation.

\begin{tabular}{|c|c|c|c|c|c|c|}
\hline $\begin{array}{l}\text { Scientific name (voucher specimen number } \\
\text { in the herbarium IEB) }\end{array}$ & Vernacular name & $\begin{array}{l}\text { Native plant } \\
\text { of Mexico }\end{array}$ & $\begin{array}{l}\text { Use Value/Dermatological } \\
\text { conditions (fidelity level) }\end{array}$ & $\begin{array}{l}\text { Mode of preparation by inhabitants } \\
\text { from the Purépecha Plateau }\end{array}$ & $\begin{array}{l}\text { Ethnomedicinal studies worldwide } \\
\text { mentioning the use of the species for } \\
\text { dermatological conditions }\end{array}$ & References \\
\hline Salvia mexicana L. (256921) & contrabemberecua & yes & $\begin{array}{l}0.05 / \text { rash }(75), \text { insect bites } \\
(25)\end{array}$ & $\begin{array}{l}\text { The infusion of its leaves is taken } \\
\text { orally and used in fomentation form } \\
\text { and for washing skin. Leaves are } \\
\text { directly rubbed on the affected skin } \\
\text { area. }\end{array}$ & $\begin{array}{l}\text { Mexican traditional medicine for treating } \\
\text { skin bumps. }\end{array}$ & $\begin{array}{l}\text { Navarro Pérez and } \\
\text { Avendaño Reyes, } \\
2002 .\end{array}$ \\
\hline Salvia microphylla Kunth (256917) & mirto & yes & $\begin{array}{l}0.05 / \text { rash (50), hematomas } \\
(25) \text { skin inflammation }(25)\end{array}$ & $\begin{array}{l}\text { The infusion of the aerial part is } \\
\text { taken orally, for washing skin and in } \\
\text { fomentation form. }\end{array}$ & $\begin{array}{l}\text { Mexico, it is used in dermal problems such } \\
\text { as pimples, rash, measles and for treating } \\
\text { scarlet fever. }\end{array}$ & BDMTM, 2009. \\
\hline \multicolumn{7}{|l|}{ Lauraceae } \\
\hline Persea americana Mill. (256873) & aguacate & yes & $\begin{array}{l}0.08 / \text { cuts }(42.9) \text {, } \\
\text { hematomas }(28.6) \text {, skin } \\
\text { inflammation (28.6) } \\
\text { blemishes (14.3), hair fall } \\
(14.3),\end{array}$ & $\begin{array}{l}\text { The infusion and decoction of leaves } \\
\text { and seeds are used in fomentation } \\
\text { form and for washing skin. The fruit } \\
\text { is crushed and directly applied on the } \\
\text { skin area. }\end{array}$ & $\begin{array}{l}\text { Mexico, for treating tinea pedis, scabies, } \\
\text { rash, bruises, hair loss, wounds and sores. } \\
\text { In Morocco, for hair care. }\end{array}$ & $\begin{array}{l}\text { Hurtado-Rico et al., } \\
\text { 2006; Andrade-Cetto, } \\
\text { 2009; BDMTM, 2009; } \\
\text { El Mansouri et al., } \\
\text { 2011; Bello-González } \\
\text { et al., } 2015 \text {. }\end{array}$ \\
\hline \multicolumn{7}{|l|}{ Malvaceae } \\
\hline $\begin{array}{l}\text { Ceiba aesculifolia (Kunth) Britten \& Baker } \\
\text { f. }(256868)\end{array}$ & pochote & yes & $0.02 / \operatorname{rash}(100)$ & The infusion of its bark is taken orally. & $\begin{array}{l}\text { Mexico, for treating dermatitis and snake } \\
\text { bites. }\end{array}$ & BDMTM, 2009. \\
\hline Malva parviflora L. (256848) & malva silvestre & no & $\begin{array}{l}0.13 / \text { rash }(81.8) \text {, cuts } \\
\text { (36.4), pruritus }(18.2) \text {, skin } \\
\text { inflammation }(9.1) \text {, skin } \\
\text { bumps (9.1) }\end{array}$ & $\begin{array}{l}\text { The infusion of the aerial part or the } \\
\text { whole plant is used for baths, washes } \\
\text { and in fomentation form. }\end{array}$ & $\begin{array}{l}\text { Mexico, it is used for treating the } \\
\text { inflammation caused by blows, wounds } \\
\text { or abscesses. Additionally, it is used for } \\
\text { deep bumps, cuts or wounds, stings of } \\
\text { poisonous animals or spiders, lesions on } \\
\text { the lips and purulent abscesses. } \\
\text { In Al-Rass province, Saudi Arabia, it is } \\
\text { used for promoting hair growth. In Tigray } \\
\text { region, Northern Ethiopia, it is used for } \\
\text { treating anthrax. }\end{array}$ & $\begin{array}{l}\text { Andrade-Cetto, 2009; } \\
\text { BDMTM, 2009; El- } \\
\text { Ghazali et al., 2010; } \\
\text { Gebrezgabiher et al., } \\
2013 \text {. }\end{array}$ \\
\hline Sida haenkeana C. Presl (256849) & huinarí & yes & $\begin{array}{l}0.13 \text { skin bumps }(100) \text {, cuts } \\
(9.1) \text {, hematomas }(9.1)\end{array}$ & $\begin{array}{l}\text { The flowers and leaves, mainly the } \\
\text { leaves, are crushed with salt and the } \\
\text { paste is applied on the affected area. }\end{array}$ & Not reported. & \\
\hline
\end{tabular}


Appendix: Continuation.

\begin{tabular}{|c|c|c|c|c|c|c|}
\hline $\begin{array}{l}\text { Scientific name (voucher specimen number } \\
\text { in the herbarium IEB) }\end{array}$ & Vernacular name & $\begin{array}{l}\text { Native plant } \\
\text { of Mexico }\end{array}$ & $\begin{array}{l}\text { Use Value/Dermatological } \\
\text { conditions (fidelity level) }\end{array}$ & $\begin{array}{l}\text { Mode of preparation by inhabitants } \\
\text { from the Purépecha Plateau }\end{array}$ & $\begin{array}{l}\text { Ethnomedicinal studies worldwide } \\
\text { mentioning the use of the species for } \\
\text { dermatological conditions }\end{array}$ & References \\
\hline \multicolumn{7}{|l|}{ Meliaceae } \\
\hline Azadirachta indica A. Juss. (256893) & neem & no & $\begin{array}{l}0.02 / \text { cuts }(100), \text { skin } \\
\text { inflammation }(50), \text { psoriasis } \\
(50)\end{array}$ & $\begin{array}{l}\text { The infusion of the leaves is taken } \\
\text { orally and used in fomentation form } \\
\text { and for washing skin. }\end{array}$ & $\begin{array}{l}\text { this plant appears in classical texts of } \\
\text { Ayurveda for its positive effects on the } \\
\text { skin. In Trinidad and Tobago, it is used } \\
\text { for treating measles. In Morag, Nepal, it is } \\
\text { used for scabies. In Coastal Karnataka, for } \\
\text { wound healing and for managing herpes, } \\
\text { scabies and ringworm. In Manipuri } \\
\text { tribal community, Bangladesh, for skin } \\
\text { diseases. }\end{array}$ & $\begin{array}{l}\text { Van der Nat et al., } \\
\text { 1991; Acharya and } \\
\text { Pokhrel, 2006; Lans, } \\
\text { 2007; Parvez Rana et } \\
\text { al., 2010; Bhandary } \\
\text { and Chandrashekar, } \\
\text { 2011; Bhat et al., } \\
\text { 2014. }\end{array}$ \\
\hline
\end{tabular}

\section{Moraceae}

Ficus carica L. (256883)

higo

no $\quad 0.03 /$ skin bumps $(100)$
The latex from leaves or stems is directly applied on the affected area.
Mexico for calluses, warts and

Italy, and Spain, for treating warts.
Guarrera et al., 2005

BDMTM, 2009

Benítez et al., 2010; Khabbach et al., 2012.

\section{Moringaceae}

Moringa oleifera Lam. (256836)

moringa

no

0.03/skin inflammation

(100), infections with

The infusion of the leaves is taken

orally and used in fomentation form

abscesses (33.3), psoriasis The seeds are eaten.

(33.3)

\section{Musaceae}

Musa paradisiaca $\mathrm{L}$.

plátano

no

0.06/fungal infections

(40.0), skin inflammation

(40.0), skin bumps (20.0)

The skin of the fruit is rubbed on the affected area. The seed is broken and the infusion of this is taken orally.

\section{Myrtaceae}

Luma apiculata (DC.) Burret (256872) arrayán

bella rosa no

0.03/rash (66.7), skin bumps (33.3)

Psidium sartorianum (O. Berg) Nied (256892)

yes $\quad 0.01 /$ rash (100)

The infusion of the aerial part is used for washing skin.

The infusion of its aerial parts is used for washing skin.
Ugandan rural communities for treating skin diseases. In Karnataka, India for eczema and for treating sores at the tip of penis. In Madhupur forest region of Bangladesh, for treating sores.

Mexican traditional medicine, as cicatrizing agent. In Lawachara National Park, Bangladesh, for cut injury. In Valsad district, Gujarat, it is used for calluses.

Harsha et al., 2003; Manzur-ul-Kadir Mia et al., 2009; Kasolo et al., 2010; Bhat et al., 2014.

BDMTM, 2009; Shah et al., 2011; Uddin et al., 2012.

\section{Torri, 2013.} women after childbirth.

Mexican traditional medicine for scabies, BDMTM, 2009 hematomas, as cicatrizing and haemostatic agent. 
Appendix: Continuation.

\begin{tabular}{|c|c|c|c|c|c|c|}
\hline $\begin{array}{l}\text { Scientific name (voucher specimen number } \\
\text { in the herbarium IEB) }\end{array}$ & Vernacular name & $\begin{array}{l}\text { Native plant } \\
\text { of Mexico }\end{array}$ & $\begin{array}{l}\text { Use Value/Dermatological } \\
\text { conditions (fidelity level) }\end{array}$ & $\begin{array}{l}\text { Mode of preparation by inhabitants } \\
\text { from the Purépecha Plateau }\end{array}$ & $\begin{array}{l}\text { Ethnomedicinal studies worldwide } \\
\text { mentioning the use of the species for } \\
\text { dermatological conditions }\end{array}$ & References \\
\hline \multicolumn{7}{|l|}{ Onagraceae } \\
\hline Oenothera rosea L'Hér. ex Aiton (256845) & hierba del golpe & yes & $\begin{array}{l}0.21 / \text { hematomas }(94.4) \text {, } \\
\text { inflammation ( } 33.3), \text { cuts } \\
(5.6), \text { rash }(5.6)\end{array}$ & $\begin{array}{l}\text { The infusion of the aerial part is used } \\
\text { for washing skin and in fomentation } \\
\text { form on the affected area. The aerial } \\
\text { part is crushed, and the paste is applied } \\
\text { on the site of injury. }\end{array}$ & $\begin{array}{l}\text { Mexican traditional medicine for treating } \\
\text { apparent skin conditions such as infected } \\
\text { lesions, bumps, sores, itching, erysipelas } \\
\text { and scabies. }\end{array}$ & $\begin{array}{l}\text { Navarro Pérez and } \\
\text { Avendaño Reyes, } \\
\text { 2002; Hurtado- } \\
\text { Rico et al., 2006; } \\
\text { Andrade-Cetto, 2009; } \\
\text { BDMTM, 2009; } \\
\text { Bello-González et al., } \\
2015 .\end{array}$ \\
\hline \multicolumn{7}{|l|}{ Papaveraceae } \\
\hline Argemone ochroleuca Sweet (256880) & chicalote & yes & $\begin{array}{l}0.02 / \text { superficial infections } \\
(100), \text { cuts }(50)\end{array}$ & $\begin{array}{l}\text { The decoction of the aerial part is } \\
\text { used for washing skin. The alcoholic } \\
\text { extract of the aerial part is applied in } \\
\text { fomentation form. }\end{array}$ & $\begin{array}{l}\text { Mexico, it is used for the treatment of } \\
\text { ringworm, scabies, hair loss, pimples, } \\
\text { hives and warts. } \\
\text { In Hawassa city, southern Ethiopia, for } \\
\text { wound healing. }\end{array}$ & $\begin{array}{l}\text { BDMTM, 2009; } \\
\text { Regassa, 2013; Ávila- } \\
\text { Uribe et al., } 2016 .\end{array}$ \\
\hline Bocconia arborea S. Watson (256901) & inguambo & yes & $\begin{array}{l}0.13 / \text { cuts }(72.7) \text {, } \\
\text { hematomas (36.4), skin } \\
\text { inflammation (18.2) }\end{array}$ & $\begin{array}{l}\text { The decoction of the bark is used in } \\
\text { fomentation form and for washing } \\
\text { skin. A piece of bark is placed in water } \\
\text { and taken orally. }\end{array}$ & $\begin{array}{l}\text { Mexican traditional medicine, for the } \\
\text { treatment of scabies and warts. }\end{array}$ & BDMTM, 2009. \\
\hline \multicolumn{7}{|l|}{ Phytolaccaceae } \\
\hline Phytolacca icosandra L. (256897) & conguera & yes & $\begin{array}{l}0.05 / \text { superficial infections } \\
(50), \text { cuts }(25), \text { psoriasis } \\
(25), \text { skin care }(25)\end{array}$ & $\begin{array}{l}\text { The infusion of the aerial part is used } \\
\text { for washing skin. The leaves and fruits } \\
\text { are rubbed directly in the area. }\end{array}$ & $\begin{array}{l}\text { Mexico, it is used to prevent hair loss, } \\
\text { against ringworm, measles, and dandruff. } \\
\text { Additionally, it is used against the fungi } \\
\text { and for treating skin bumps or wounds. }\end{array}$ & $\begin{array}{l}\text { BDMTM, 2009; } \\
\text { Bello-González et al., } \\
\text { 2015; Ávila-Uribe et } \\
\text { al., } 2016 \text {. }\end{array}$ \\
\hline
\end{tabular}


Appendix: Continuation.

\begin{tabular}{|c|c|c|c|c|c|c|}
\hline $\begin{array}{l}\text { Scientific name (voucher specimen number } \\
\text { in the herbarium IEB) }\end{array}$ & Vernacular name & $\begin{array}{l}\text { Native plant } \\
\text { of Mexico }\end{array}$ & $\begin{array}{l}\text { Use Value/Dermatological } \\
\text { conditions (fidelity level) }\end{array}$ & $\begin{array}{l}\text { Mode of preparation by inhabitants } \\
\text { from the Purépecha Plateau }\end{array}$ & $\begin{array}{l}\text { Ethnomedicinal studies worldwide } \\
\text { mentioning the use of the species for } \\
\text { dermatological conditions }\end{array}$ & References \\
\hline \multicolumn{7}{|l|}{ Plantaginaceae } \\
\hline Plantago major L. (256841) & llantén & no & $\begin{array}{l}0.05 / \text { cuts }(75), \text { infections } \\
\text { with abscesses }(50), \\
\text { superficial infections ( } 50) \text {, } \\
\text { skin inflammation (25), } \\
\text { psoriasis (25) }\end{array}$ & $\begin{array}{l}\text { The infusion of the aerial part is used } \\
\text { in fomentation form and for washing } \\
\text { skin. }\end{array}$ & $\begin{array}{l}\text { Mexico, as an anti-inflammatory for } \\
\text { bumps, wounds, mumps and abscesses. } \\
\text { For pimples, wounds and purulent sores, } \\
\text { to suppress hematomas. At Arunachal } \\
\text { Pradesh, India for treating wound and } \\
\text { inflammations. In Kurdish ethnomedicine, } \\
\text { it is used topically by its analgesic, } \\
\text { antinflammatory and wound healing } \\
\text { properties. Among Croatians living in } \\
\text { Northern Istria, it is applied externally } \\
\text { as hemostatic and cicatrizing agent. In } \\
\text { Zangelanlo district, Northeast Iran, for } \\
\text { treating skin allergies. In Iran, for treating } \\
\text { eczema. }\end{array}$ & $\begin{array}{l}\text { Guarrera et al., 2005; } \\
\text { Pieroni and Giusti, } \\
\text { 2008; BDMTM, 2009; } \\
\text { Das et al., 2012; Amiri } \\
\text { and Joharchi, 2013; } \\
\text { Tahvilian et al., 2014. }\end{array}$ \\
\hline
\end{tabular}

\section{Poaceae}

Avena sativa L.

avena

no

$0.02 /$ skin bumps (50.0),

skin care (50.0)

maíz

yes

0.02/fungal infections (100) maiz

\section{Polemoniaceae}

Loeselia mexicana (Lam.) Brand (256864)

espinosilla

yes

0.08/hair fall (42.9), skin
inflammation (28.6), insect

bites (28.6), varicella

(28.6), fungal infections

The seed is soaked in water and

ground, the resulting paste is used for preparing a soap that is applied on the skin area.

called "nejayo" is used to wash the

affected area.
Mexican traditional medicine, for treating wounds, skin impurities and melasma. In

Iran, for treating acne.

Mexico, for skin care and as a hot bath in the "temazcal". In Iran, as antiinflammatory agent.
BDMTM, 2009;

Amiri and Joharchi, 2013.

BDMTM, 2009; Amiri and Joharchi, 2013.

\section{Polygonaceae}

Polygonum capitatum Buch.-Ham. ex D. Don (256886) hierba de la golondrina no
The infusion of the aerial part is taken orally, being also used in baths and washes.

Mexico, for hair loss, dandruff, oily hair, erysipelas, rubella, abscesses, and varicose veins.
BDMTM, 2009; Bello-González et al., 2015; Ávila-Uribe et al., 2016. 
Appendix: Continuation.

\begin{tabular}{|c|c|c|c|c|c|c|}
\hline $\begin{array}{l}\text { Scientific name (voucher specimen number } \\
\text { in the herbarium IEB) }\end{array}$ & Vernacular name & $\begin{array}{l}\text { Native plant } \\
\text { of Mexico }\end{array}$ & $\begin{array}{l}\text { Use Value/Dermatological } \\
\text { conditions (fidelity level) }\end{array}$ & $\begin{array}{l}\text { Mode of preparation by inhabitants } \\
\text { from the Purépecha Plateau }\end{array}$ & $\begin{array}{l}\text { Ethnomedicinal studies worldwide } \\
\text { mentioning the use of the species for } \\
\text { dermatological conditions }\end{array}$ & References \\
\hline \multicolumn{7}{|l|}{ Proteaceae } \\
\hline $\begin{array}{l}\text { Macadamia integrifolia Maiden \& Betche } \\
\text { (256891) }\end{array}$ & $\begin{array}{l}\text { nogal de } \\
\text { macadamia }\end{array}$ & no & $\begin{array}{l}0.03 / \text { hair fall }(66.7) \text {, cuts } \\
(33.3)\end{array}$ & $\begin{array}{l}\text { The decoction from leaves is used in } \\
\text { washing skin. }\end{array}$ & $\begin{array}{l}\text { Brazilian traditional medicine, it is used } \\
\text { against vitiligo. }\end{array}$ & Okuma et al., 2011. \\
\hline \multicolumn{7}{|l|}{ Rosaceae } \\
\hline $\begin{array}{l}\text { Eriobotrya japonica (Thunb.) Lindl. } \\
\text { (256853) }\end{array}$ & níspero & no & $\begin{array}{l}0.02 / \text { cuts }(100), \text { superficial } \\
\text { infections }(100)\end{array}$ & $\begin{array}{l}\text { The infusion from its leaves is used for } \\
\text { washing skin. }\end{array}$ & $\begin{array}{l}\text { Mexican traditional medicine, for treating } \\
\text { varicose veins. In Jammu District, India, } \\
\text { for the treatment of skin diseases. }\end{array}$ & $\begin{array}{l}\text { BDMTM, 2009; Priya } \\
\text { and Sharma, } 2014 .\end{array}$ \\
\hline Prunus persica (L.) Batsch (256866) & durazno & no & $\begin{array}{l}\text { 0.03/rash (100), hematomas } \\
(33.3)\end{array}$ & $\begin{array}{l}\text { The infusion of its leaves is taken } \\
\text { orally. It is also used for washing skin. }\end{array}$ & $\begin{array}{l}\text { Mexico, for dry skin, rash, scrapes and } \\
\text { wounds. }\end{array}$ & $\begin{array}{l}\text { Andrade-Cetto, 2009; } \\
\text { BDMTM, } 2009 .\end{array}$ \\
\hline Rosa gallica L. (256842) & rosa de castilla & no & $\begin{array}{l}0.08 / \text { skin bumps }(57.1) \text {, } \\
\text { rash }(42.9) \text {, pruritus }(28.6) \text {, } \\
\text { blemishes }(14.3)\end{array}$ & $\begin{array}{l}\text { The infusion of its flowers is taken } \\
\text { orally. Additionally, it is used for } \\
\text { washing skin and in fomentation form. }\end{array}$ & $\begin{array}{l}\text { Mediterranean coast of Spain, its petals } \\
\text { are a part of an ointment used for skin } \\
\text { diseases. }\end{array}$ & Pascual, 1994. \\
\hline \multicolumn{7}{|l|}{ Rutaceae } \\
\hline Citrus aurantifolia Swingle & limón & no & $\begin{array}{l}0.06 / \text { blemishes (20), cuts } \\
(20) \text {, fungal infections }(20) \text {, } \\
\text { infections with abscesses } \\
\text { (20), psoriasis (20) }\end{array}$ & $\begin{array}{l}\text { The juice of the fruit is used in } \\
\text { infusions and ointments to be applied } \\
\text { on the affected area. The juice is } \\
\text { placed in a copper bowl and allowed } \\
\text { to stand overnight to be applied to the } \\
\text { skin area in the morning. }\end{array}$ & $\begin{array}{l}\text { Mexican traditional medicine, for treating } \\
\text { skin spots and scabies. In Kelantan, } \\
\text { Malaysia, for dranfurt treatment. In coastal } \\
\text { parts of Karnataka, India, for boils. In } \\
\text { Hmar tribe, in India for purulent boils. In } \\
\text { Nicaragua Atlantic Coast for itching. }\end{array}$ & $\begin{array}{l}\text { Barrett, 1994; Ong } \\
\text { and Nordiana, 1999; } \\
\text { BDMTM, 2009; Nath } \\
\text { and Choudhury, 2010; } \\
\text { Bhat et al., 2014. }\end{array}$ \\
\hline Ruta graveolens L. (256890) & ruda & no & $\begin{array}{l}0.08 / \text { hematomas } \\
(28.6) \text {, rash (28.6), skin } \\
\text { inflammation (14.3), } \\
\text { psoriasis (14.3) skin bumps } \\
(14.3)\end{array}$ & $\begin{array}{l}\text { The infusion of the aerial part is used } \\
\text { for washing skin and in fomentation } \\
\text { form. The aerial part is roasted and } \\
\text { placed in alcohol for foments. Fresh } \\
\text { leaves are rubbed directly into the } \\
\text { affected area. }\end{array}$ & $\begin{array}{l}\text { Mexico, for treating varicose veins and } \\
\text { wounds. } \\
\text { In Mediterranean traditional medicine, } \\
\text { against acne and as a topical analgesic. }\end{array}$ & $\begin{array}{l}\text { Pollio et al., 2008; } \\
\text { BDMTM, } 2009 .\end{array}$ \\
\hline \multicolumn{7}{|l|}{ Salicaceae } \\
\hline Salix bonplandiana Kunth (256902) & eucalipto & yes & $\begin{array}{l}0.03 / \text { skin care }(66.7) \text {, skin } \\
\text { inflammation }(33.3)\end{array}$ & $\begin{array}{l}\text { The infusion of the leaves is used } \\
\text { as a hot bath in the "temazcal". The } \\
\text { alcoholic extract from the leaves is } \\
\text { used in fomentation form. }\end{array}$ & $\begin{array}{l}\text { Mexican traditional medicine, for treating } \\
\text { gangrene. }\end{array}$ & BDMTM, 2009. \\
\hline \multicolumn{7}{|l|}{ Scrophulariaceae } \\
\hline Buddleja sessiliflora Kunth (256904) & tepoja & yes & $\begin{array}{l}0.02 / \text { hair fall }(100), \text { rash } \\
(50.0)\end{array}$ & $\begin{array}{l}\text { The root is crushed and applied on the } \\
\text { area. Root decoction is taken orally } \\
\text { and used for washing skin. }\end{array}$ & $\begin{array}{l}\text { Mexico, it is used in swellings, varicose } \\
\text { veins and for healing wounds. }\end{array}$ & BDMTM, 2009. \\
\hline
\end{tabular}


Appendix: Continuation.

\begin{tabular}{|c|c|c|c|c|c|c|}
\hline $\begin{array}{l}\text { Scientific name (voucher specimen number } \\
\text { in the herbarium IEB) }\end{array}$ & Vernacular name & $\begin{array}{c}\text { Native plant } \\
\text { of Mexico }\end{array}$ & $\begin{array}{l}\text { Use Value/Dermatological } \\
\text { conditions (fidelity level) }\end{array}$ & $\begin{array}{l}\text { Mode of preparation by inhabitants } \\
\text { from the Purépecha Plateau }\end{array}$ & $\begin{array}{l}\text { Ethnomedicinal studies worldwide } \\
\text { mentioning the use of the species for } \\
\text { dermatological conditions }\end{array}$ & References \\
\hline \multicolumn{7}{|l|}{ Schisandraceae } \\
\hline Illicium verum Hook. f. & anís estrella & no & $\begin{array}{l}0.10 / \text { skin bumps }(100) \text {, rash } \\
(33.3), \text { pruritus }(11.1)\end{array}$ & $\begin{array}{l}\text { The infusion of its fruits is taken orally } \\
\text { and used for washing skin and in } \\
\text { fomentation form. }\end{array}$ & $\begin{array}{l}\text { Malaysia, it is used in a mixture for } \\
\text { itching. }\end{array}$ & $\begin{array}{l}\text { Ong and Nordiana, } \\
1999 .\end{array}$ \\
\hline \multicolumn{7}{|l|}{ Solanaceae } \\
\hline $\begin{array}{l}\text { Brugmansia suaveolens (Humb. \& Bonpl. ex } \\
\text { Willd.) Sweet (256884) }\end{array}$ & florifundio & no & $\begin{array}{l}\text { 0.03/hematomas (33.3), } \\
\text { infections with abscesses } \\
\text { (33.3), skin inflammation } \\
\text { (33.3) }\end{array}$ & $\begin{array}{l}\text { The infusion of its flowers and leaves } \\
\text { is used in fomentation form and for } \\
\text { washing skin. }\end{array}$ & $\begin{array}{l}\text { Among Zapotecs of the Isthmus-Sierra } \\
\text { (Oaxaca, Mexico), it is used for } \\
\text { dermatological illness. In Sarban Hills, } \\
\text { Abbottabad, KP, Pakistan, for treating skin } \\
\text { disorders. }\end{array}$ & $\begin{array}{l}\text { Frei et al., 1998; Ijaz } \\
\text { et al., } 2016 .\end{array}$ \\
\hline Nicotiana tabacum $\mathrm{L}$. & tabaco & no & $\begin{array}{l}0.02 / \text { fungal infections }(50) \\
\text { psoriasis }(50)\end{array}$ & $\begin{array}{l}\text { The ash from the cigarettes is placed } \\
\text { on the affected skin area. }\end{array}$ & $\begin{array}{l}\text { Mexico, for treating wounds, bruises, } \\
\text { burns, pimples, rash, erysipelas, } \\
\text { dermatitis, scabies, insect bites, herpes and } \\
\text { inflammation. In } \\
\text { Southern Ethiopia, against skin infections } \\
\text { and external parasites. Among the } \\
\text { tribals of Mizoram, India, for treating } \\
\text { leucoderma, wounds and cuts }\end{array}$ & $\begin{array}{l}\text { Bhardwaj and Gakhar, } \\
\text { 2005; BDMTM, 2009; } \\
\text { Tolossa et al., } 2013 .\end{array}$ \\
\hline Physalis pubescens L. (256874) & tomate & yes & $0.08 /$ rash $(100)$ & $\begin{array}{l}\text { The infusion of the fruit, mainly the } \\
\text { shell, is used for baths and for washing } \\
\text { skin. }\end{array}$ & $\begin{array}{l}\text { Mexican traditional medicine, for treating } \\
\text { wounds. In Spain, for burns. }\end{array}$ & $\begin{array}{l}\text { BDMTM, 2009; } \\
\text { Benítez et al., } 2010 .\end{array}$ \\
\hline $\begin{array}{l}\text { Solanum nigrescens M. Martens \& Galeotti } \\
\text { (256857) }\end{array}$ & hierba mora & yes & $\begin{array}{l}0.09 / \text { rash }(87.5) \text {, skin } \\
\text { bumps }(12.5) \text {, varicella } \\
(12.5)\end{array}$ & $\begin{array}{l}\text { The infusion of fruits and leaves is } \\
\text { used for baths and for washing skin. } \\
\text { The fruits are rubbed directly on the } \\
\text { affected area. }\end{array}$ & $\begin{array}{l}\text { Mexico, for wounds, eczema, erysipelas, } \\
\text { bruises, rash, wounds, burns, abscesses, } \\
\text { pimples, inflammation, insect bites, } \\
\text { healing and hair care. }\end{array}$ & $\begin{array}{l}\text { Navarro Pérez and } \\
\text { Avendaño Reyes, } \\
\text { 2002; Andrade-Cetto, } \\
\text { 2009; BDMTM, 2009; } \\
\text { Ávila-Uribe et al., } \\
\text { 2016. }\end{array}$ \\
\hline Solanum tuberosum $\mathrm{L}$. & papa & no & $\begin{array}{l}0.05 / \text { burns }(75), \text { insect bites } \\
(25)\end{array}$ & The tuber shell is rubbed in the area. & $\begin{array}{l}\text { Mexico, to treat dandruff, hair loss, burns, } \\
\text { swellings. In North of Morocco, for the } \\
\text { treatment of burns. In Bangladesh, for } \\
\text { swelling and skin rashes. In Romania, for } \\
\text { wounds and swelling. }\end{array}$ & $\begin{array}{l}\text { Pieroni et al., 2003; } \\
\text { BDMTM, 2009; } \\
\text { Khabbach et al., 2012; } \\
\text { Mahbubur Rahman et } \\
\text { al., } 2015 \text {. }\end{array}$ \\
\hline
\end{tabular}


Appendix: Continuation.

\begin{tabular}{|c|c|c|c|c|c|c|}
\hline $\begin{array}{l}\text { Scientific name (voucher specimen number } \\
\text { in the herbarium IEB) }\end{array}$ & Vernacular name & $\begin{array}{l}\text { Native plant } \\
\text { of Mexico }\end{array}$ & $\begin{array}{l}\text { Use Value/Dermatological } \\
\text { conditions (fidelity level) }\end{array}$ & $\begin{array}{l}\text { Mode of preparation by inhabitants } \\
\text { from the Purépecha Plateau }\end{array}$ & $\begin{array}{l}\text { Ethnomedicinal studies worldwide } \\
\text { mentioning the use of the species for } \\
\text { dermatological conditions }\end{array}$ & References \\
\hline \multicolumn{7}{|l|}{ Tropaeolaceae } \\
\hline Tropaeolum majus L. (256895) & mastuerzo & no & $\begin{array}{l}0.03 / \text { cuts }(33.3) \text {, } \\
\text { hematomas ( } 33.3) \text {, } \\
\text { Infections with abscesses } \\
\text { (33.3), skin inflammation } \\
\text { (33.3), superficial infections } \\
\text { (33.3) }\end{array}$ & $\begin{array}{l}\text { The infusion of the aerial part is used } \\
\text { in fomentation form. The alcoholic } \\
\text { extract from the seeds is used for } \\
\text { washing skin affected area. }\end{array}$ & $\begin{array}{l}\text { Mexico, for treating melasma and skin } \\
\text { bumps. The Angami Tribe, India, used it } \\
\text { to cure boils. Used in Uruguay, to prevent } \\
\text { hair fall and dandruff, for } \\
\text { inflammation, small burns and skin } \\
\text { infections. }\end{array}$ & $\begin{array}{l}\text { BDMTM, 2009; } \\
\text { Grosso, 2010; Chase } \\
\text { and Singh, 2013; } \\
\text { Ávila-Uribe et al., } \\
2016 .\end{array}$ \\
\hline \multicolumn{7}{|l|}{ Urticaceae } \\
\hline Urtica subincisa Benth. (256906) & ortiga & yes & $\begin{array}{l}0.17 / \text { skin inflammation } \\
(80), \text { varicose veins }(60) \text {, } \\
\text { skin bumps }(6.7)\end{array}$ & $\begin{array}{l}\text { The alcoholic extract of the aerial part } \\
\text { is applied in the form of fomentations. } \\
\text { The infusion of its leaves is taken } \\
\text { orally. }\end{array}$ & Not reported. & \\
\hline \multicolumn{7}{|l|}{ Verbenaceae } \\
\hline Aloysia citrodora Paláu (256894) & cedrón & yes & $\begin{array}{l}\text { 0.03/skin inflammation } \\
(100)\end{array}$ & $\begin{array}{l}\text { The infusion of the leaves is taken } \\
\text { orally and applied in fomentation } \\
\text { form. }\end{array}$ & $\begin{array}{l}\text { Southwest of Morocco, it is used for skin } \\
\text { care }\end{array}$ & Ouhaddou et al., 2015. \\
\hline Verbena carolina L. (256854) & verbena & yes & 0.06/hair fall (100) & $\begin{array}{l}\text { The infusion of the whole plant is used } \\
\text { to wash the area. }\end{array}$ & $\begin{array}{l}\text { Mexico, it is used to treat hair loss, } \\
\text { dandruff, rash, bruising, skin infection, } \\
\text { pimples and wounds. }\end{array}$ & $\begin{array}{l}\text { Navarro Pérez and } \\
\text { Avendaño Reyes, } \\
\text { 2002; BDMTM, 2009; } \\
\text { Bello-González et al., } \\
2015 .\end{array}$ \\
\hline
\end{tabular}

